\title{
MAINTAINING SOCIAL COHESION IN THE PEOPLE'S REPUBLIC OF CHINA IN THE NEW ERA
}

Minsoo Lee, Edimon Ginting, Limin Wang, and Meiyan Wang

NO. 22

December 2019

\section{ADB EAST ASIA WORKING PAPER SERIES}




\section{ADB East Asia Working Paper Series}

\section{Maintaining Social Cohesion in the People's Republic of China in the New Era}

Minsoo Lee, Edimon Ginting, Limin Wang, and Meiyan Wang

No. 22 | December 2019
Minsoo Lee is head of Knowledge Hub, People's Republic of China Resident Mission, Asian Development Bank (ADB).

Edimon Ginting is deputy director general, Economic Research and Regional Cooperation Department, ADB.

Limin Wang is a professor at London School of Economics.

Meiyan Wang is a professor of Institute of Population and Labor Economics at Chinese Academy of Social Sciences. 
(C) 2019 Asian Development Bank

6 ADB Avenue, Mandaluyong City, 1550 Metro Manila, Philippines

Tel +632632 4444; Fax +6326362444

www.adb.org

Some rights reserved. Published in 2019.

Publication Stock No. WPS190598-2

DOI: http://dx.doi.org/10.22617/WPS190598-2

The views expressed in this publication are those of the authors and do not necessarily reflect the views and policies of the Asian Development Bank (ADB) or its Board of Governors or the governments they represent.

ADB does not guarantee the accuracy of the data included in this publication and accepts no responsibility for any consequence of their use. The mention of specific companies or products of manufacturers does not imply that they are endorsed or recommended by ADB in preference to others of a similar nature that are not mentioned.

By making any designation of or reference to a particular territory or geographic area, or by using the term "country" in this document, $A D B$ does not intend to make any judgments as to the legal or other status of any territory or area.

This work is available under the Creative Commons Attribution 3.0 IGO license (CC BY 3.0 IGO)

https://creativecommons.org/licenses/by/3.0/igo/. By using the content of this publication, you agree to be bound by the terms of this license. For attribution, translations, adaptations, and permissions, please read the provisions and terms of use at https://www.adb.org/terms-use\#openaccess.

This CC license does not apply to non-ADB copyright materials in this publication. If the material is attributed to another source, please contact the copyright owner or publisher of that source for permission to reproduce it. ADB cannot be held liable for any claims that arise as a result of your use of the material.

Please contact pubsmarketing@adb.org if you have questions or comments with respect to content, or if you wish to obtain copyright permission for your intended use that does not fall within these terms, or for permission to use the ADB logo.

Corrigenda to ADB publications may be found at http://www.adb.org/publications/corrigenda.

Notes:

In this publication, "\$" refers to United States dollars.

ADB recognizes "China” as the People's Republic of China. 


\section{CONTENTS}

FIGURES

ACKNOWLEDGMENTS $\quad v$

ABSTRACT vi vi

ABBREVIATIONS vii

$\begin{array}{ll}\text { I. INTRODUCTION } & 1\end{array}$

II. GOVERNMENT POLICIES AND OUTCOMES 2 REGARDING INCOME DISTRIBUTION

III. STRUCTURAL TRANSFORMATION AND INEQUALITY 10

IV. LOW ECONOMIC MOBILITY: STRUCTURAL SOURCES OF INEQUALITY

V. MIGRANTS AND INEQUALITY 19

VI. POLICY RECOMMENDATIONS

$\begin{array}{ll}\text { REFERENCES } & 28\end{array}$ 


\section{FIGURES}

1 Key Performance Indicators for the People's Republic of China 3 and Other Emerging Economies, 2018

2 Development Indicator Rankings of the People's Republic of China 4 among 74 Emerging Economies, 2018

3 Key Performance Indicators, 2005-2017 5

4 Interprovincial Inequality, 1990-2014 6

5 Rural and Urban per Capita Disposable Incomes, 2013-2017 7

6 Real Disposable Income per Capita by Income Group, 2013-2018 8

7 Constant Disposable Income per Capita, 2013-2018 8

8 Number of Private Firms Registered in Each Province, 2010-2017 9

9 Structural Change and Upgrading, 2010-2017 10

10 Shares of Employment by Sector, 2013 and 2017

11 Employment Trends by Sector and Skill Level, 2013-2017 12

12 Wage Ratio Trends by Sector, 2007, 2012, and 2017

13 Wage Ratios in High-Skilled Service Sectors, 2017

14 Population Aging by Sector, 2018

15 Education Inequality and Intergenerational Upward Mobility in Education 17 in Selected Countries, 2018

16 Education Gaps: Math and Reading Test Scores, 2010

17 Intergenerational Earnings Elasticity and Inequality in Selected Countries 19

18 Proportions of Migrant Populations, 201720

19 Comparisons among Rural-Urban Migrants, Urban-Urban Migrants, 21 and Urban Locals, 2010 and 2016

20 Public Spending in Selected Countries, 2017

21 Tax Levels and Structures in Selected Countries, 2017 


\section{ACKNOWLEDGMENTS}

This paper was prepared for a high-level roundtable discussion in Beijing organized by the Asian Development Bank and the National Development and Reform Commission of the People's Republic of China. The authors are grateful for helpful inputs provided by Ehtisham Ahmad, Benedict Bingham, Fan Gang, Nick Stern, Li Shi, Zhuang Juzhong, Wang Xiaolin, Raymond Gaspar, Jin Hua, and Huiyan Du. 


\begin{abstract}
This paper examines the need to reduce the rising inequality in educational opportunities, as well as the need to ensure economic security and income mobility, during the transition to high-quality development in the People's Republic of China. The achievement of these objectives is essential for maintaining social cohesion. The transition will build on the country's remarkable economic performance since the reform and opening up in 1978, in which strong and sustained growth enabled the country to reduce poverty on an unprecedented scale. This success has also brought new challenges, particularly the high level of inequality in income, wealth, opportunities, and economic insecurity. In the medium term, policies to reduce inequality should include labor-market programs for increasing skills to enhance labor mobility and reduce skill mismatches, and well-targeted and easily administered social protection systems. Longterm policies are needed to equip workers with transferable skills so they can adapt to a fast-changing labor market. The current 9 years of compulsory education should be expanded to 12 years, and combined with life-long programs for upgrading skills. Social spending can be financed through fiscal reforms to enhance the mobilization of financing, and through central-local fiscal transfers that are aligned with the levels of concentration of migrant populations.
\end{abstract}

Keywords: social cohesion, inequality, income mobility, high-quality development, People's Republic of China 


\section{ABBREVIATIONS}

DRC - Development Research Center (of the State Council)

FYP - Five-Year Plan

GDP - gross domestic product

IMF - International Monetary Fund

PRC - People's Republic of China 



\section{INTRODUCTION}

The People's Republic of China (PRC), which is now engaged in a transition to high-quality development, must reduce its rising inequality in educational opportunities, and ensure economic security and income mobility. Progress on each of these three objectives will be essential for maintaining social cohesion. This transition will build on the country's remarkable economic performance. Real gross domestic product (GDP) in the PRC has accelerated by an average of $9.5 \%$ a year since the $1980 \mathrm{~s}$. This strong and sustained growth has enabled the country to reduce its poverty rate on an unprecedented scale, raise income per capita to $\$ 10,000$, and improve the quality of employment for much of its large population. This growth has also provided the space for further policy reforms. The state leadership has balanced socialist and national objectives, while recognizing the importance of market mechanisms for efficiency gains in the economy. Enriched by economic growth, the PRC has made progress in providing social services and in enhancing the human, social, natural, and physical capital needed for modernization. The PRC was the first developing country to achieve the poverty reduction target set by the Millennium Development Goals, and the country aims to build on this achievement by eradicating extreme poverty by 2020 .

The PRC's economic success has nevertheless come at a price that will be familiar to advanced economies: It is now one of the most unequal countries in the world in terms of income, wealth, and education outcomes. There are significant barriers to mobility and economic opportunities, especially for ruralurban migrants. These inequalities, which are closely interlinked, hinder income mobility and economic security and opportunities. Compared with other upper-middle-income countries, the PRC shows much less intergenerational economic mobility, as measured by earnings elasticity and education mobility. Economic development has been uneven across regions and sectors, and income disparity, economic insecurity, and lack of educational opportunities have worsened, particularly for rural households.

Policy makers everywhere need sound advice on the complex nature of rising inequality and how best to tackle it. Inequality is an important dimension of development in its own right, but it also has consequences for how governments fight poverty and work to sustain growth. Not only does inequality dampen the poverty-reduction impact of growth, it can also affect growth itself, through a number of economic, social, and political mechanisms (Kanbur, Rhee, and Zhuang 2014). Widening inequalitywith more people at the top and bottom of the income ladder-can also mean a hollowing out of the middle class. There is a consensus among analysts on the causal link between inequality and the quality of institutions. Along several dimensions, including political and institutional stability and property rights, the negative impact of inequality on institutional quality seems to be well established, although a twoway causality is also widely recognized (Zhuang, de Dios, and Lagman-Martin 2010).

Greater inequality may lead to a political backlash in which pressure grows for governments to enact populist policy measures. In response to rising demands, the political process may favor policies that will in the short term benefit low-income groups, but could in the long term hold back efficiency and growth (Alesina and Rodrik 1994). In the PRC, where the Gini coefficient of consumption expenditure per capita worsened from 32.4 in 1990 to 43.4 in 2008, the Government of the People's Republic of China designated the building of a "harmonious society" as the development goal of its 11th Five-Year Plan (FYP), for 2006-2010. This goal was reaffirmed in the 12th FYP (2011-2015), with greater emphasis on the quality - not just the quantity - of growth, and on making growth inclusive (Kanbur, Rhee, and Zhuang 2014). 
Managing the transition to high-quality development in a way that maintains stable social cohesion is a multifaceted challenge that requires a multifaceted response. The growth model underpinning the PRC's high-quality development centers on innovation and technology advancement, the upgrading of supply value chains, and a shift out of low-value-added manufacturing. These changes will reshape demand in the labor market. Sectors with buoyant growth prospects tend to have large skill premiums and require at least a high school education; and half of the workforce in these sectors have a university education. Low-skilled manufacturing faces diminishing growth, which risks leaving the less-educated at a disadvantage, especially those with skills that are easily automated. Large sections of the workforce may therefore experience heightened insecurity, and these could be concentrated in specific communities and regions.

The outlook is by no means all negative, despite the challenges. Technology offers new opportunities for inclusive development. Advances in digital technologies are expanding e-commerce, improving financial inclusion, enhancing access to education through online learning, and broadening labor market participation through online platforms. And some labor-intensive, low-carbon, and environmentally sustainable sectors have high growth potential. Old-age care services and sustainable tourism are two examples of industries in leisure and other high-end service sectors that are likely to see a boom. But taking advantage of these opportunities will require public and private sector investment to expand access to education and upgrade workforce skills. Increasing the resilience and adaptive capacity of the workforce will be essential for maintaining social cohesion, as will ensuring that the social protection system responds to rapid changes in employment and the structure of the labor market (and the associated risks of greater economic insecurity).

The rest of the paper is ordered as follows: Section II gives an overview of government policies and outcomes with regard to income distribution. Section III examines employment trends by sector, skill level, and relative wages against the backdrop of the labor market's structural transformation. Section IV examines the sources of inequality in income, wealth, education, and economic mobility. Section $V$ looks at how migration is contributing to increased inequality. The paper then closes with policy recommendations.

\section{GOVERNMENT POLICIES AND OUTCOMES REGARDING INCOME DISTRIBUTION}

This section assesses the progress of government policies on income distribution from three perspectives: the PRC's performance compared with that of other emerging economies; the evolution of the PRC's key performance indicators since 2000; and intra-regional and interregional comparisons, including how living standards across regions have changed.

To tackle increasing income inequality, the government launched a series of policies and initiatives under the 12th FYP and the 13th FYP (2016-2020) to advance not just the quantity, but also the quality of growth. The 19th National Congress of the Communist Party of China, held in 2017, set the stage for advancing the PRC's development goals by embedding them in the governing philosophy of socialism

with Chinese characteristics. The new approach, coupled with the pursuit of well-being, seeks to make 
progress toward the previous goals of a "moderately prosperous society" and "harmonious society," while also working toward a broader vision of quality of life and sustainable well-being. The promotion of inclusive and sustainable development is now embodied in five guiding principles: innovation, coordination, green growth, sharing, and opening up. Both FYPs also set policy priorities and specific economic- and social-development targets.

How has the PRC fared in reaching the inclusive and sustainable development goals of these national plans? One way of gauging this is to use the World Economic Forum's key performance indicators (World Economic Forum 2018), which measure and evaluate the progress of a country's performance in three dimensions of inclusive and sustainable development: growth and development, inclusion, and intergenerational equity and sustainability (Figure 1). There is also the Inclusive Development Index, which is based on 12 key indicators (four for each dimension), and is used for performance tracking and cross-country comparison.

\section{Figure 1: Key Performance Indicators for the People's Republic of China} and Other Emerging Economies, 2018

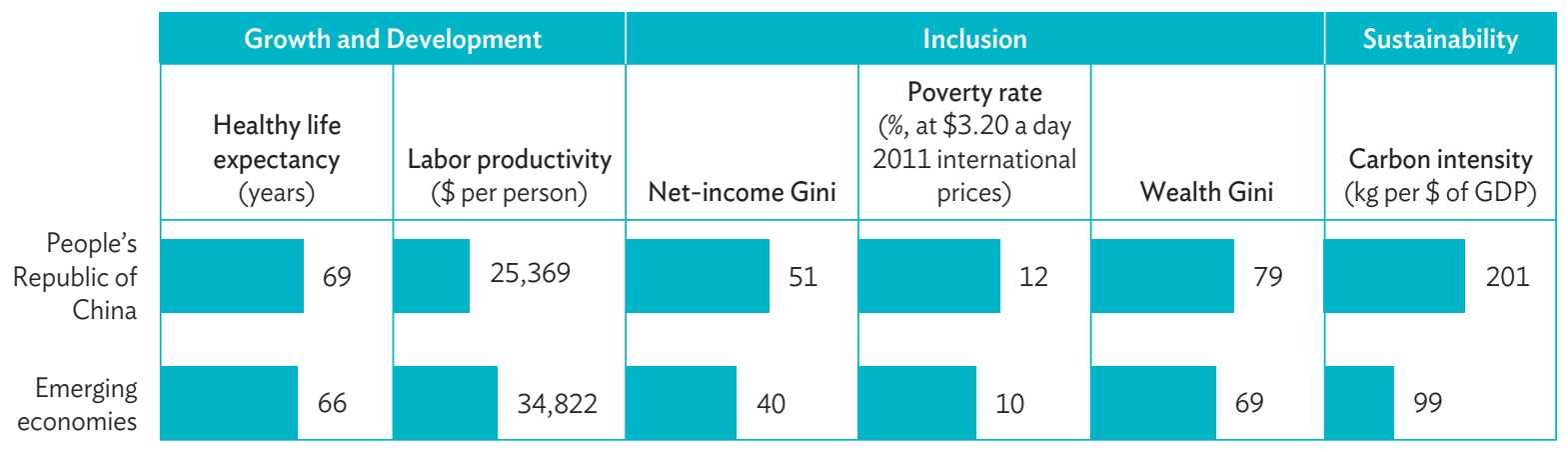

GDP = gross domestic product, $\mathrm{kg}=$ kilogram .

Source: World Economic Forum. 2018. The Inclusive Development Index 2018. Geneva.

The World Economic Forum (2018) ranked the PRC's overall inclusive development indicator at 26th among the 74 emerging economies analyzed. The PRC performed well in the growth and development dimension, ranking 6th in healthy life expectancy and 18th in labor productivity (Figure 2). But it performed poorly in the inclusion and intergenerational equity and sustainability dimensions, ranking last in inclusion, with a net-income Gini coefficient of 51, which had barely changed since 2012 (Solt 2016). This was 11 points higher than the average for the 74 economies. On wealth inequality, the PRC ranked 59th,10\% worse than the average. However, the adverse impact of rising inequality in the PRC has been mitigated by a continued and impressive reduction in absolute poverty-unlike the situation in the advanced economies. The proportion of the PRC's population living on less than $\$ 3.20$ a day fell from a third in 2012 to 12\% (World Economic Forum 2018). According to the key performance indicators, economic growth in the PRC is far from sustainable; for instance, the country ranked 65th in carbon intensity. But its emissions per unit of GDP have declined by $38 \%$ since 2012, largely because of a decreasing reliance on the manufacturing and energy-intensive sectors. 
Figure 2: Development Indicator Rankings of the People's Republic of China among 74 Emerging Economies, 2018

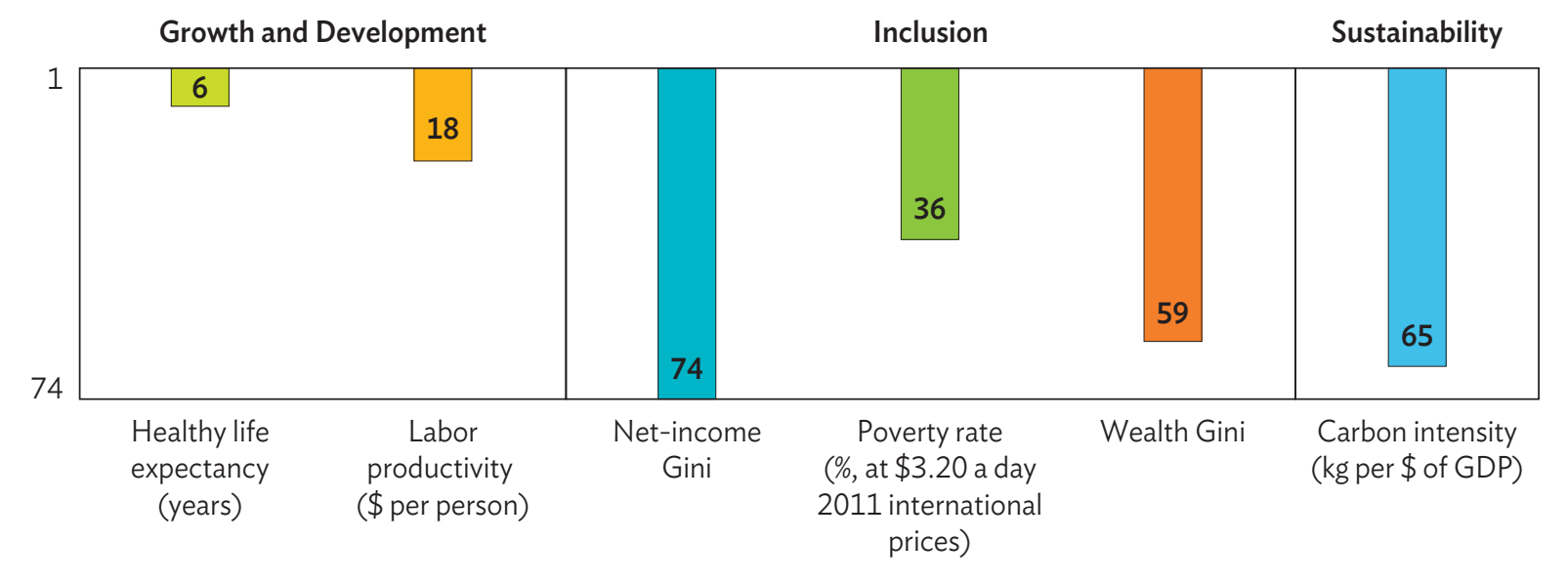

GDP = gross domestic product, $\mathrm{kg}=$ kilogram .

Source: World Economic Forum. 2018. The Inclusive Development Index 2018. Geneva.

Figure 3 tracks the trends of the PRC's key performance indicators during 2005-2017. Excellent progress was made in sustaining growth and improving human development. High economic growth of about 7\% a year was accompanied by rising labor productivity, which nearly tripled during the same period. Tertiary education expanded rapidly, coupled with higher university enrollment rate among women, which was 10\% higher than for men in 2017.

Since 2005, the PRC has made great progress in reducing poverty and narrowing urban-rural gaps. Extreme poverty is expected to be eradicated by 2020 because of extensive rural-urban migration and rising agriculture productivity. The latter is the result of rural-focused policy interventions, including investments in rural infrastructure, increased public financing to support social security in rural areas, and more targeted rural poverty-reduction programs (Li, Sato, and Sicular 2013).

Environmental sustainability remains a challenge. The PRC is making important progress in reducing carbon intensity through structural upgrading and the use of more renewable energy, such as hydropower and wind, solar, and nuclear power. But it is still among the highest-emitting countries, accounting for $26 \%$ of global greenhouse gas emissions. 'This is largely due to the population's size and continued heavy reliance on fossil fuel. The PRC's success in achieving environmentally sustainable development will be pivotal for global efforts to reduce the risks of climate change and environmental degradation.

The top emitting economies are, in descending order: the United States, the PRC, India, the Russian Federation, Japan, and the European Union. All of them combined account for $68 \%$ of global greenhouse gas emissions. 


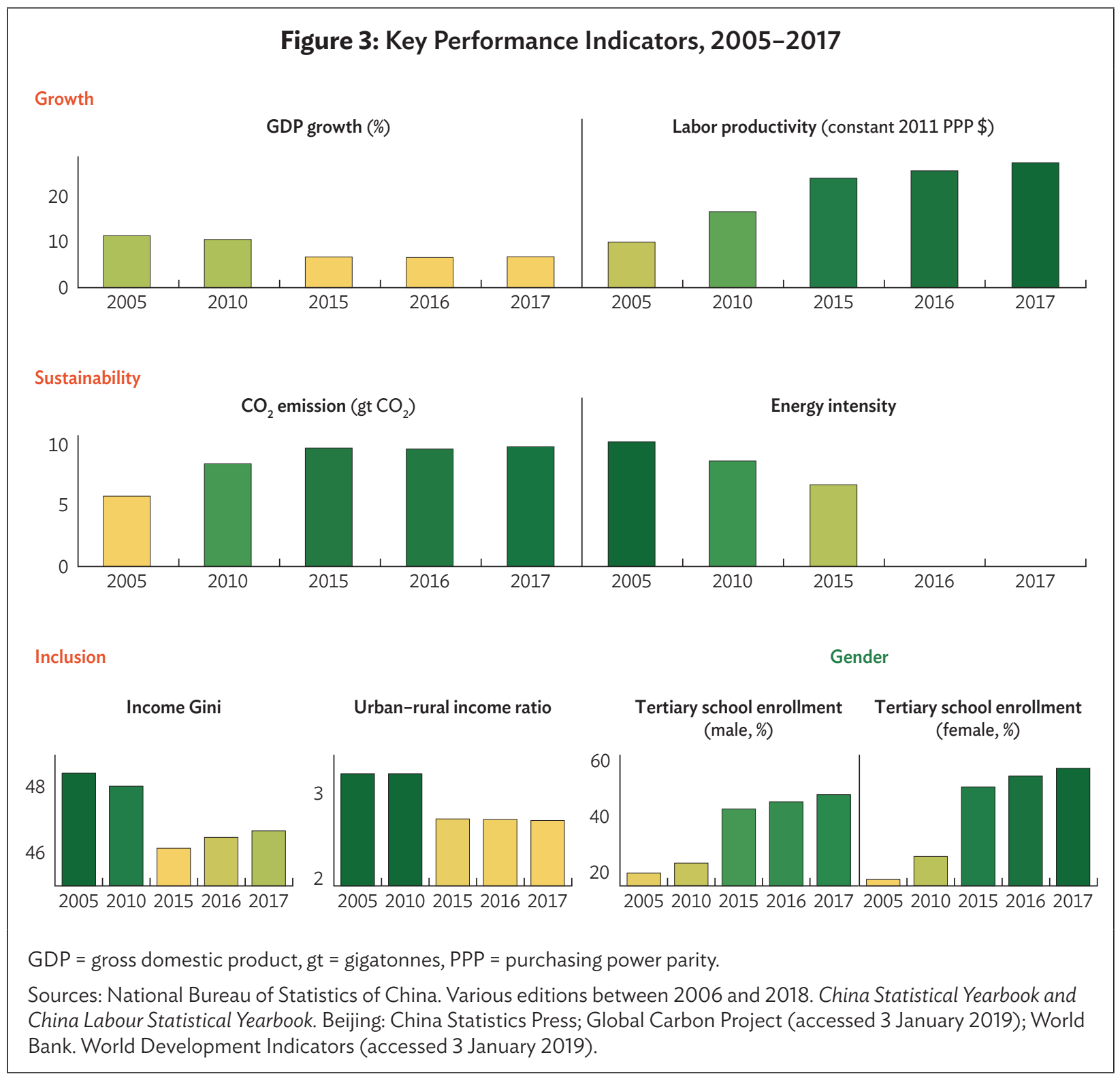

The rebalancing of regional development through geographically targeted public investment was a key component of the 12th and 13th FYPs. The PRC's regional strategy is essentially two-pronged. The first centers on the western and central regions, focusing on basic infrastructure, ecological protection, and coordinated development with regard to urbanization, industrialization, informatization, and agricultural modernization. The second centers on the northeast, with the goal of accelerating the structural upgrading of the region's old industrial base by developing emerging industries and service sectors. A key policy question is how successful this regional development strategy will be in raising living standards and tackling regional disparities. 
Figure 4 shows a downward trend in interprovincial inequality. With this analysis, it is important to understand economic mobility across regions, as this will show how income growth rates can vary, and the extent of spatial convergence, as this will determine long-term regional disparities.

Figure 4: Interprovincial Inequality, 1990-2014

$(\%)$

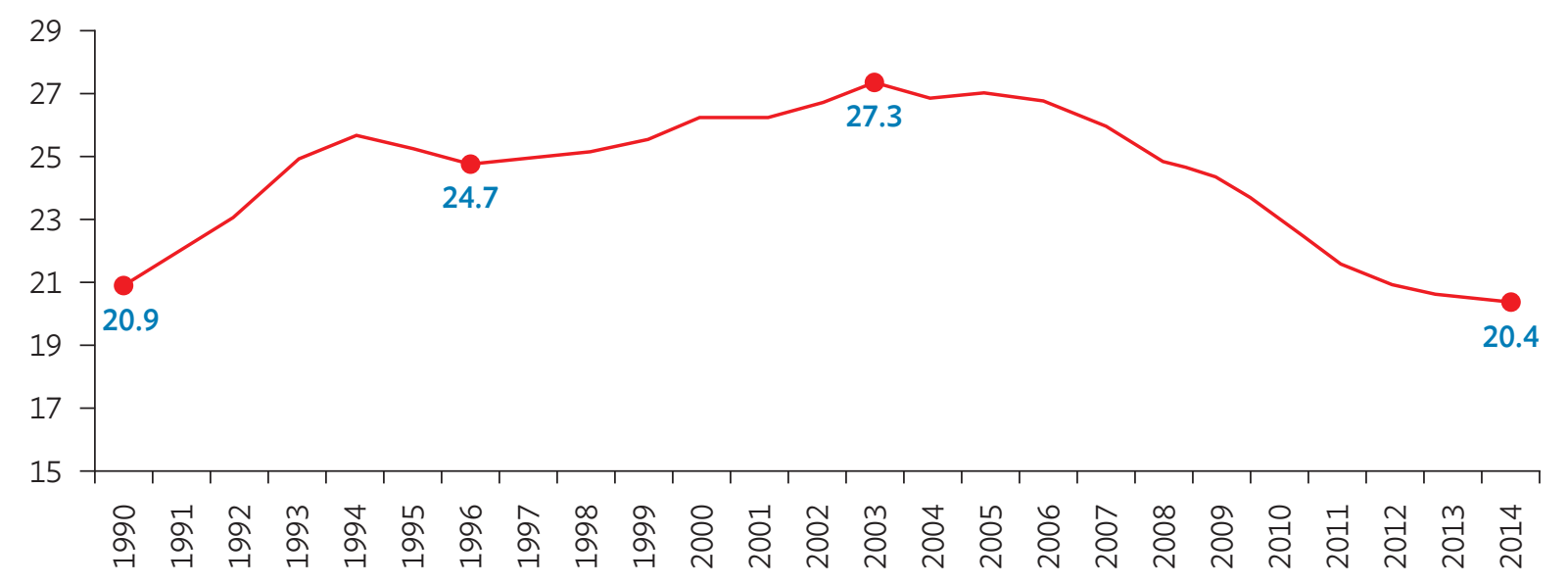

Source: Zhuang, J., and S. Li. 2016. Understanding Recent Trends in Income Inequality in the People's Republic of China. ADB Economics Working Paper Series. No. 489. Manila: ADB.

Using data from several annual editions of the China Statistical Yearbook, published by the National Bureau of Statistics of China, one can track the changes in living standards separately for rural and urban areas, based on disposable income per capita estimated from household surveys. Figure 5 shows the rural and urban areas in each province classified as either "upward movers" or "downward movers" during 2013-2017.2 Among the rural upward movers, the rural areas in Tibet and Chongqing made the biggest gains in raising living standards, with disposable income per capita rising more than 5\% during that period. The urban areas in Tibet rose $6 \%$ and in Xinjiang 4\%. Among the downward movers, both the rural and urban areas performed poorly in four traditionally industrial provinces: the major coal producer Shanxi and the old manufacturing bases of Jilin, Liaoning, and Heilongjiang, all of which fell behind compared with the other provinces. These findings provide some evidence that the PRC's regional rebalancing strategy, structural upgrading, and shifts to a low-carbon economy have generated different welfare impacts across regions.

2 The concept of economic mobility in this context refers to intraprovincial mobility. This identifies the changes in average living standards in each province over a period of time, grouping provinces into upward movers, downward movers, and nonmovers. Mobility is calculated by subtracting the percent deviation from the national median from 2013 to 2017. Upward movers are defined as provinces whose disposable income per capita rose more than $2 \%$, and downward movers as provinces whose disposable income per capita decreased more than $2 \%$. Nonmovers are provinces that did not rise or fall by more than $2 \%$. About one-third of provinces were nonmovers (i.e., with relatively little change in living standards during 2013-2017). 


\section{Figure 5: Rural and Urban per Capita Disposable Incomes, 2013-2017}

$(\%)$

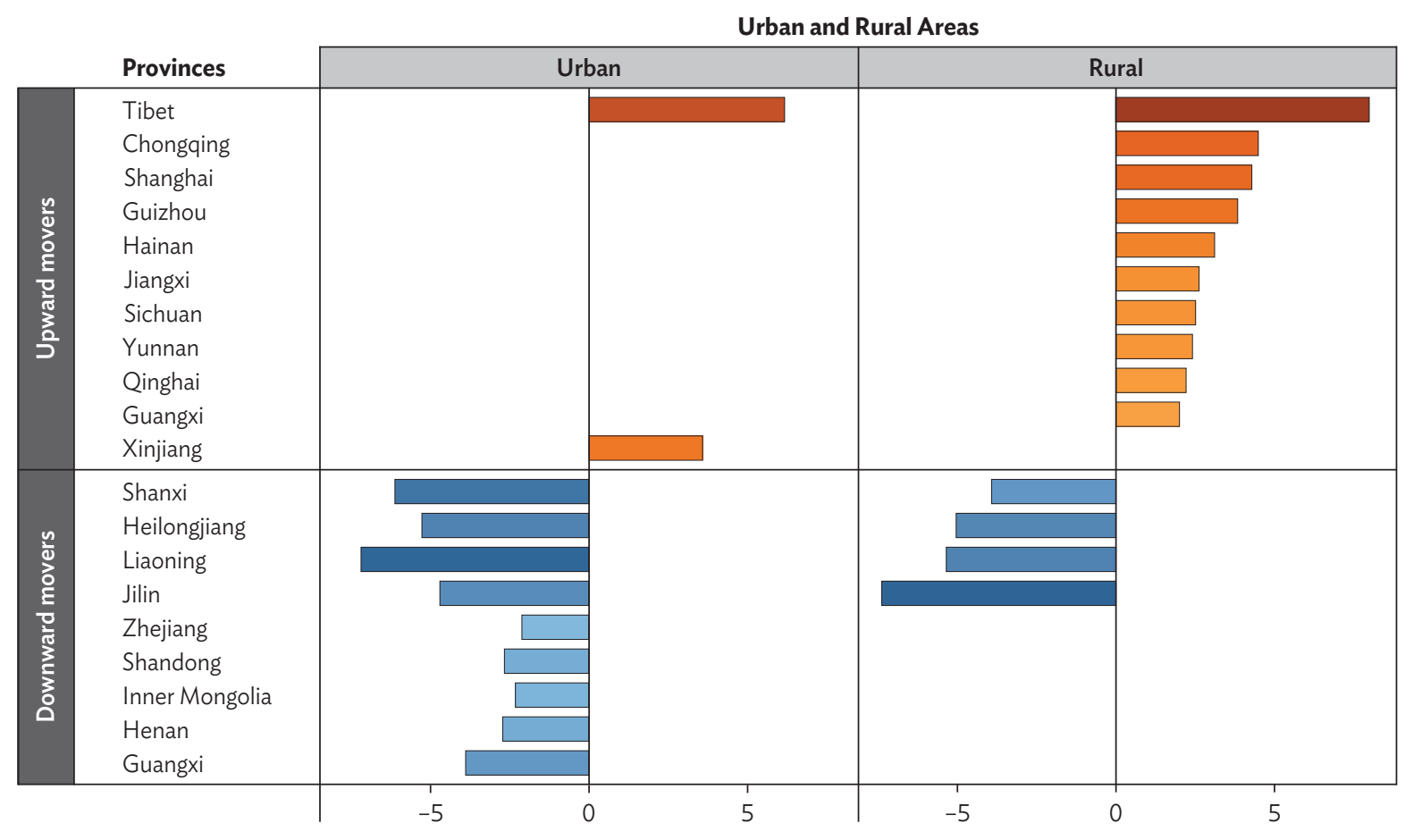

Sources: National Bureau of Statistics of China. Various editions between 2014 and 2018. China Statistical Yearbook. Beijing: China Statistics Press; CEIC Data. CEIC China Premium Database (accessed 13 February 2019).

Even though rising inequalities in income and opportunity are threats to social cohesion, they have not had a major impact so far in the PRC. There seem to be two reasons for this. First, poverty continues to decline, and extreme poverty will likely be eradicated by 2020. Second, the disposable income of the lowest $20 \%$ of income earners has gradually risen (Figure 6 ), in contrast to the trends in many other emerging economies and in high-income countries. Even so, the rate of growth of the disposable incomes of the PRC's lowest income groups has been sluggish (Figure 7).

An analysis of private sector activity as measured by firm registrations during 2010-2017 sheds useful light on how the PRC could make more progress toward eliminating its spatial disparities. Figure 8 shows that the three richest municipalities (Beijing, Shanghai, and Tianjin) and the three richest provinces (Guangdong, Jiangsu, and Zhejiang) had below-median growth in the registration of firms over this period. At the same time, the poorest provinces-Guangxi, Guizhou, Jiangxi, Tibet, and Qinghaishowed growth above the median. This suggests that less-developed provinces and municipalities, with initial lower growth and private investment, offered higher returns on investment, and were thus able to attract more private firms. Another reason could be that new firms found it harder to enter established markets. This suggests a need to ramp up regional development, particularly by means of regionally targeted infrastructure investments that could potentially attract private investors and contribute to a spatial convergence in living standards across provinces. 
Figure 6: Real Disposable Income per Capita by Income Group, 2013-2018 (CNY'O00)

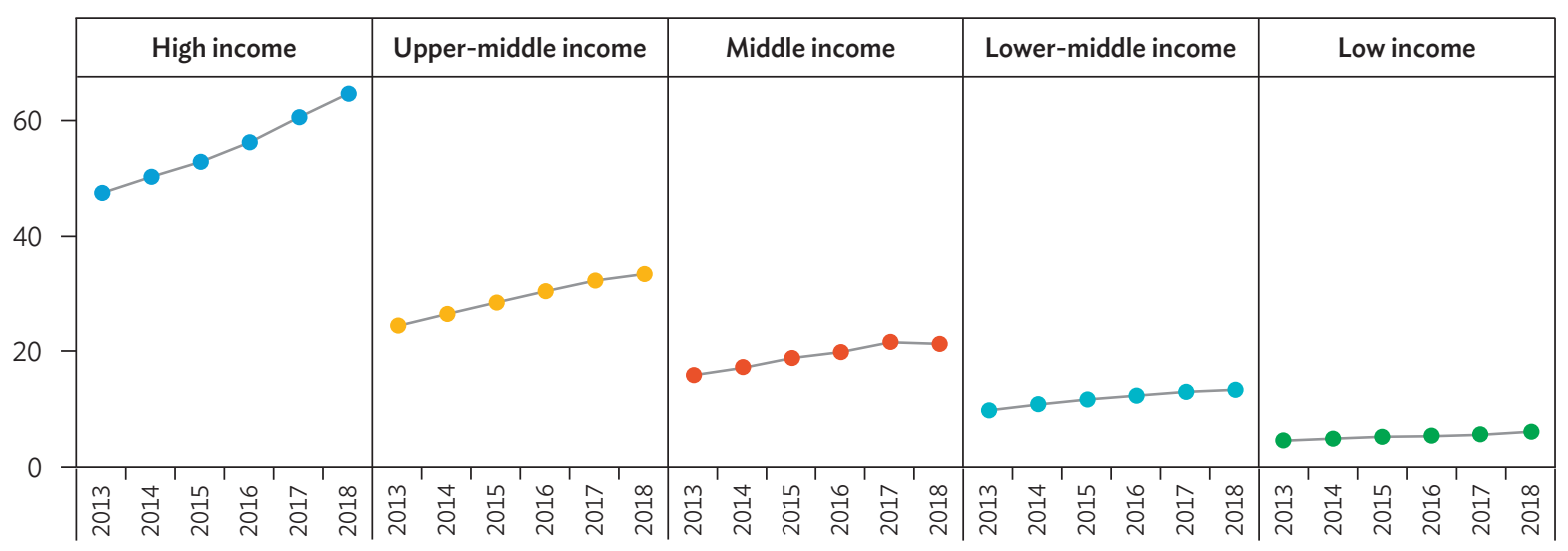

CNY = yuan.

Note: The real disposable incomes shown in this figure are in 2013 yuan.

Source: CEIC Data. CEIC China Premium Database (accessed 3 June 2019).

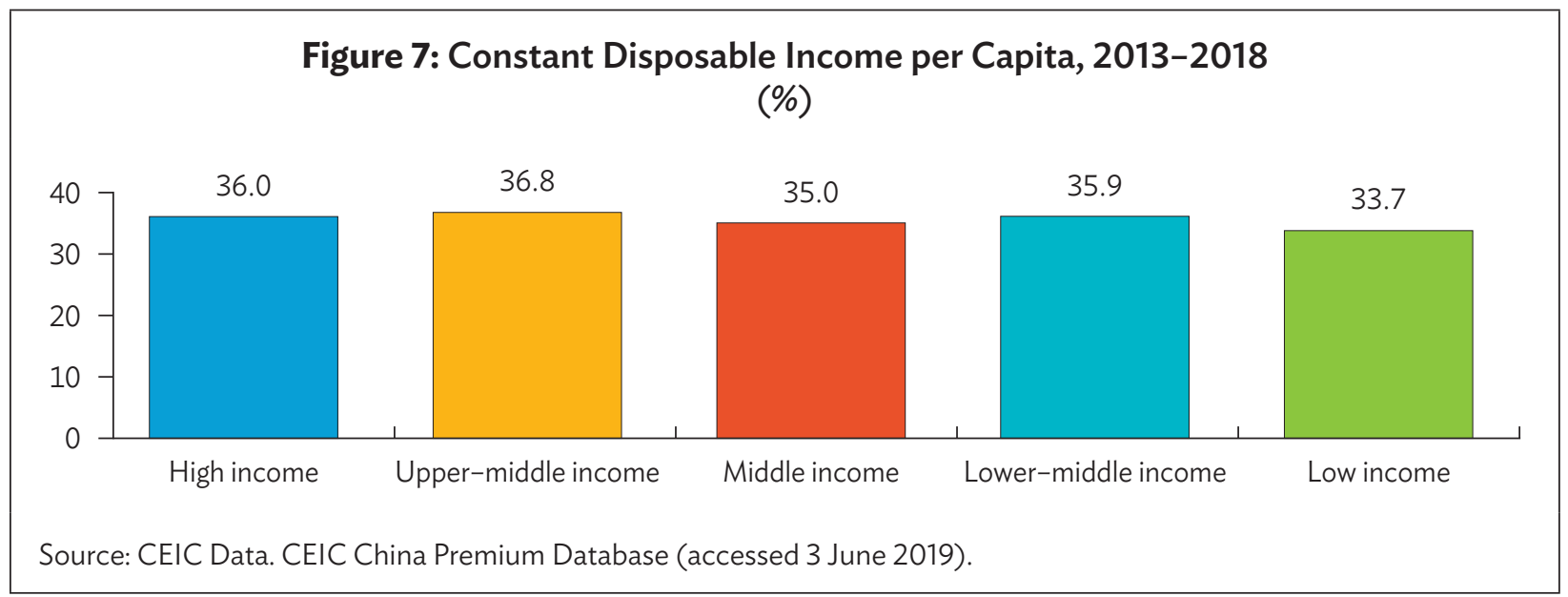

The experience of Beijing's coal phase-out program-which involved the closure, readjustment, and reorganization of coal mines-provides insights into how coordinated regional investment projects can achieve low-carbon transition and mitigate the social and economic impacts of the transition on communities (Gass, Duan, and Gerasimchuk 2016). Under the program, which lasted from 1997 to 2015, 1,150 small mines were closed in the Fangshan and Mengtougou districts of Beijing (with a combined population of 180,000), as well as three large coal-fired power plants located in these districts. ${ }^{3}$

3 The power plants were replaced by four heating and power cogeneration centers, which use clean gas and provide heating and electricity to Beijing. 
Figure 8: Number of Private Firms Registered in Each Province, 2010-2017

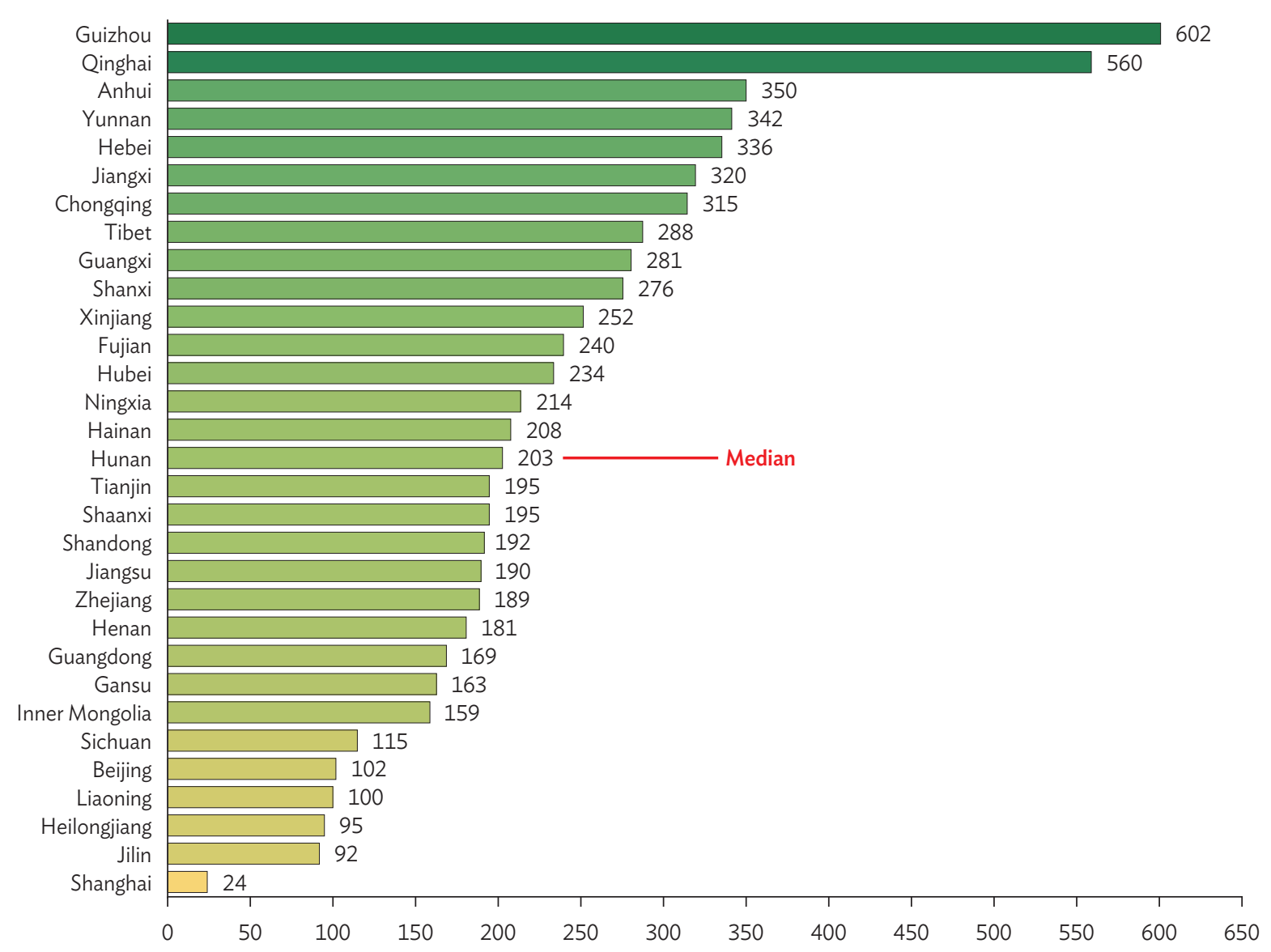

Sources: National Bureau of Statistics of China. 2011. China Statistical Yearbook 2011. Beijing: China Statistics Press; 2018. China Statistical Yearbook 2018. Beijing: China Statistics Press.

These measures reduced annual coal use by 9.2 million metric tons; cut carbon emissions by about 30 million tons; and reduced sulfur dioxide by 10,000 tons, nitrogen oxide by 19,000 tons, and dust by 3,000 tons.

As part of the coal phase-out program, major infrastructure projects, including highways, real estate development, and leisure facilities, were carried out to connect Fangshan and Mengtougou to central Beijing. The aim was to get people to move to these areas, invest in property there, and thus help to boost the local economies. The infrastructure projects were implemented with the financial support of the central and local governments. During the 12th FYP, the government also stepped up efforts to rehabilitate disused, closed, and abandoned coal mines, repurposing them to help improve the water-conservation infrastructure and ecosystems. Some workers from the closed coal mines were transferred to new jobs created by ecological rehabilitation projects, or they found jobs in an emerging local service sector. 


\section{STRUCTURAL TRANSFORMATION AND INEQUALITY}

Since around 2010, the PRC's economy has been characterized by salient shifts in the components of its GDP and by structural upgrading. The private sector's rapid expansion has been accompanied by a reduced role for state-owned enterprises. This has reshaped the sectoral distribution of employment and created a demand for different skill sets. Figure 9 traces this process, showing the extent to which the rise of the private sector coincided with a decline in the roles of agriculture, mining, and energy-intensive industries in the economy. Technology-based and energy-efficient modern manufacturing, and the service sector (modern and traditional), have become the drivers of economic growth and job creation.

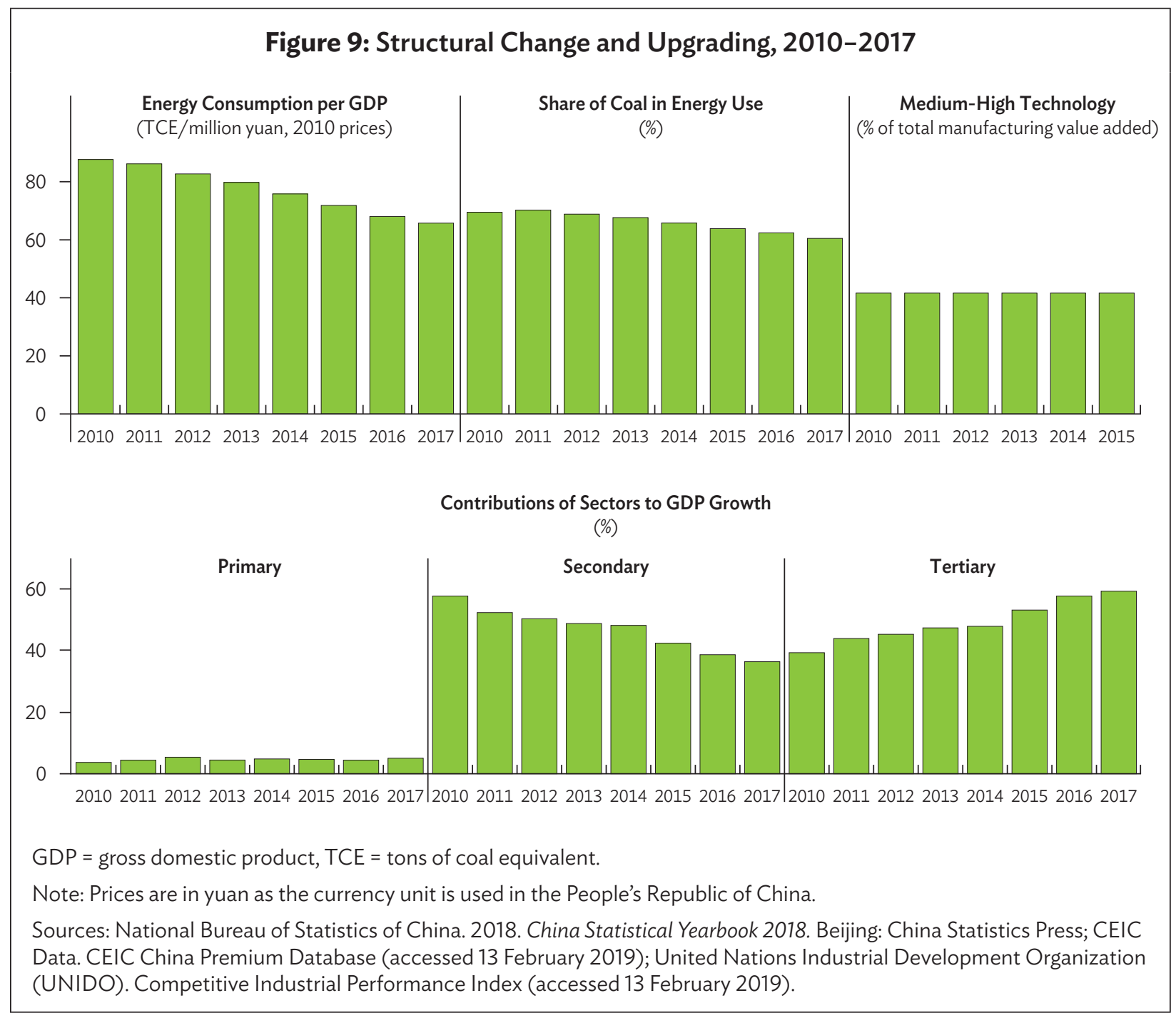


Figure 10 shows the extent to which the shares of employment attributed to agriculture and mining shrank between 2013 and 2017, as the PRC upgraded its economy and underwent further urbanization. ${ }^{4}$ At the same time, however, employment steadily increased in education, social services, healthcare, and finance.

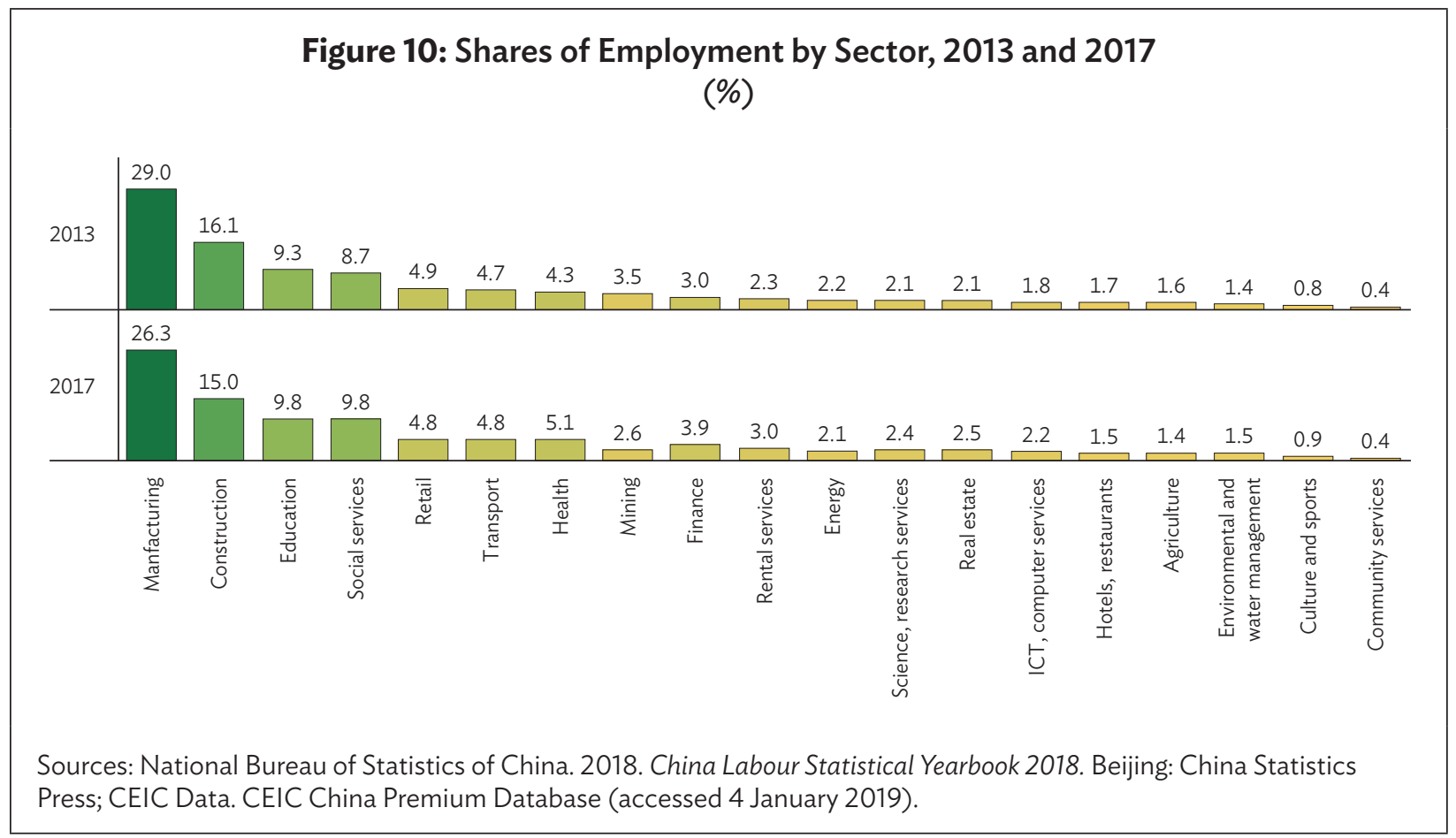

Employment in manufacturing fell by 1.7\% - a significant decline-from 2013 to 2017, although manufacturing remained the largest sector for employment, accounting for about one-third of all workers. Rising labor costs and advances in technology could explain the decline. Many multinationals that produce labor-intensive goods, such as textiles and apparel, have been seeking lower-cost locations outside the PRC — for example, in Bangladesh and Viet Nam.

Increased global concern about the adverse impact on employment of the fourth industrial revolution, with its intensified use of industrial robotics, 3D printing, and digital technologies in manufacturing processes, is highly pertinent to the PRC. Many assembly lines have already been automated. ${ }^{5}$

$4 \quad$ To simplify the trend analysis, nine aggregate categories were formed based on a regrouping of 20 sectors: agriculture, fishing and forestry, mining, manufacturing, energy, construction, wholesale and retail, transportation, hotels and catering, information and communication technology (ICT), software and internet services, financial intermediation, real estate leasing and business services, scientific research and technical services, public sector management, household services, education, health and social services, culture, and sports and entertainment.

5 The five major markets for robotics, representing $73 \%$ of the total sales in 2017, are (in descending order) the PRC, Japan, the Republic of Korea, the United States, and Germany. The PRC has been the world's biggest robotics market since 2013, accounting for 36\% of total sales in 2017 (International Federation of Robotics 2018). 
The impact of job displacement could be even more widespread in the coming decades, as the PRC is already the world's largest market for robotics installation, and the robotics market there is expected to continue showing dynamic growth. The country's total installations of robotics increased by 59\% (to 138,000 units) during 2016-2017, higher than the total robot-installation sales in Europe and the Americas combined (International Federation of Robotics 2018).

Figure 11 shows employment trends by sector and skill level during 2013-2017. Nine categories of employment are defined based on a combination of 20 sectors and three levels of educational attainment (a proxy for skill levels). ${ }^{6}$ The largest increases in employment were in the middle- and highskilled service jobs. The share of high-skilled service jobs of total employment rose $21 \%$ in that period, followed by high-skilled health sector jobs, with $17 \%$ growth. ${ }^{7}$ The share of middle-skilled service jobs also grew, by $13 \%$ in private sector services and $10 \%$ in social services. ${ }^{8}$ The share of low-skilled jobs, which do not require a high school education, fell during this period, most notably in agriculture, industry (also for middle-skilled workers), and services.

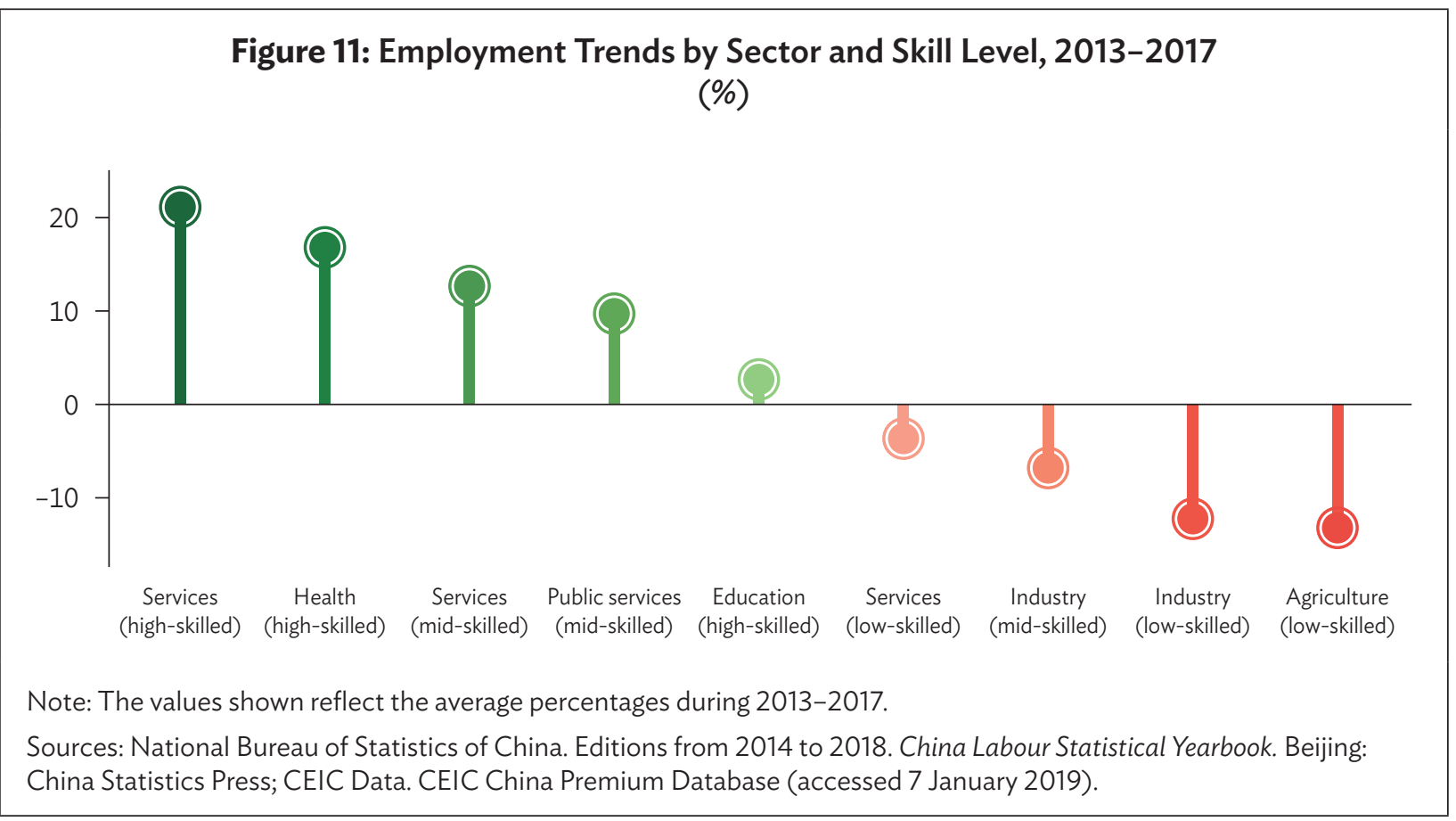

6 The education and skill levels of specific sectors are determined on the basis of the distribution of educational attainment for the 20 sectors (National Bureau of Statistics of China 2017). Low-skilled sectors are defined as those in which over $70 \%$ of the workforce have a middle school education or below, middle-skilled sectors are those in which about $50 \%$ of the workforce have a high school education, and high-skilled sectors are those in which over $50 \%$ have college bachelor's degree or above.

7 Middle- and high-skilled services include ICT, software development and internet-related services, financial intermediation, leasing and business management, and scientific research.

8 These include jobs in real estate, water conservation, environmental management, public infrastructure management, law, and public services. 
Figure 11 indicates that workers with a low level of education (middle school or less) and those with skills that are easily replaceable by automation face poor employment prospects as the PRC moves up supply value chains and shifts to high-skilled service sectors. Rural-urban migrant workers, who are disproportionately represented on manufacturing assembly lines and in low-skilled services, will likely be stuck in low-wage and low-security jobs unless policies are urgently put in place to expand their access to training programs that are combined with social protection schemes.

Figure 12 shows that, although relative wages by sector were stable from 2007 to 2017, high-skilled service sectors such as financial intermediation commanded the largest skill premiums. This is further demonstrated in Figure 13, which indicates that the average wage in 2017 for capital market services (under the rubric of financial intermediation) was 3.67 times higher than the national average. General financial services followed, at 2.56 times higher.

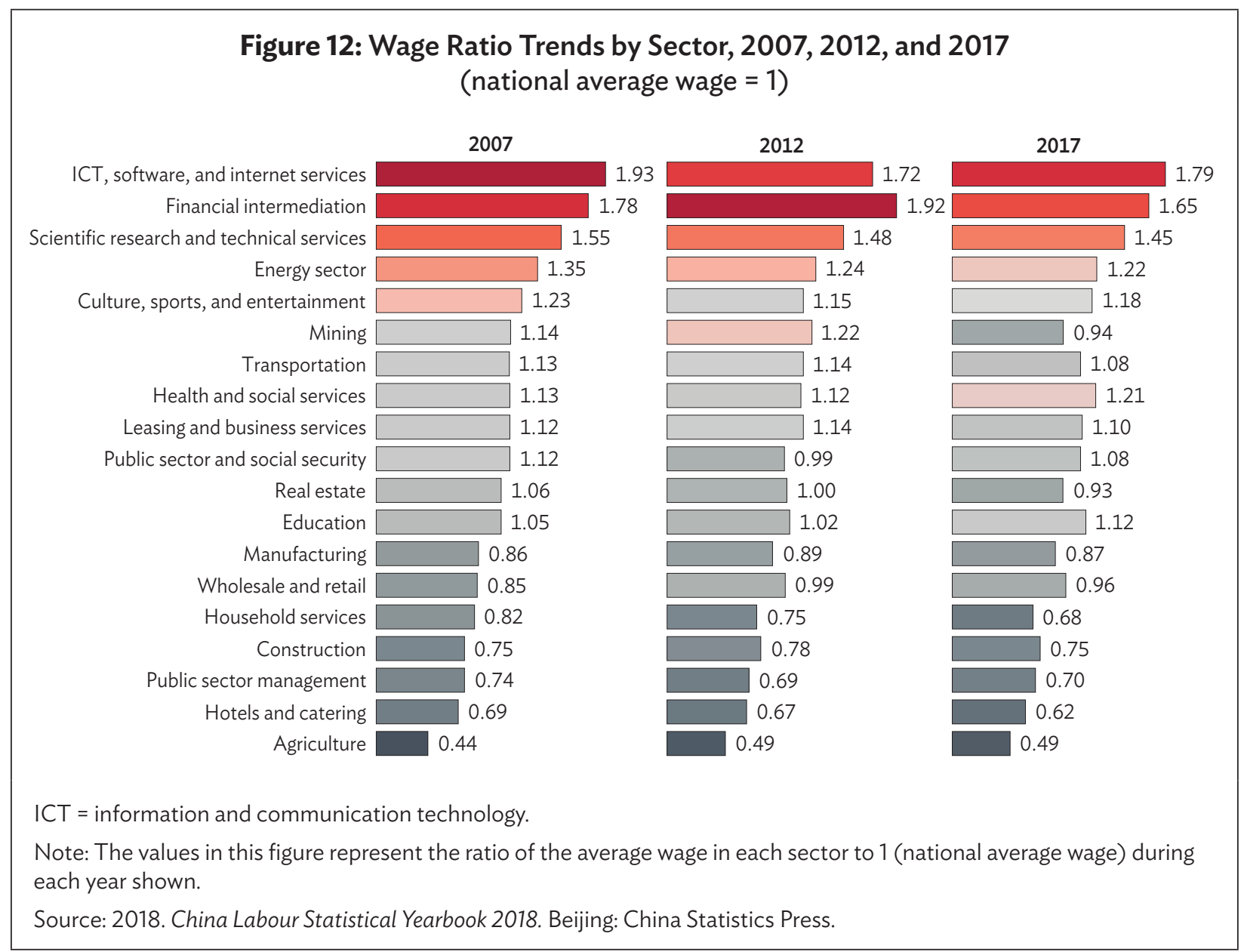




\section{Figure 13: Wage Ratios in High-Skilled Service Sectors, 2017 (national average wage $=1$ )}

\begin{tabular}{|c|c|c|}
\hline \multirow{4}{*}{$\begin{array}{l}\text { Financial } \\
\text { Intermediation }\end{array}$} & \multirow{4}{*}{$\begin{array}{l}\text { Capital market services } \\
\text { General financial services } \\
\text { Monetary and financial services } \\
\text { Insurance services }\end{array}$} & 3.67 \\
\hline & & 2.56 \\
\hline & & 2.04 \\
\hline & & 0.92 \\
\hline \multirow{3}{*}{$\begin{array}{l}\text { ICT, Software, and } \\
\text { Internet Services }\end{array}$} & \multirow{3}{*}{$\begin{array}{l}\text { Internet-related services } \\
\text { Software and ICT services } \\
\text { ICT }\end{array}$} & 2.40 \\
\hline & & 2.09 \\
\hline & & 1.35 \\
\hline \multirow{2}{*}{$\begin{array}{l}\text { Leasing and } \\
\text { Business Services }\end{array}$} & Business services & 1.10 \\
\hline & Leasing services & 1.01 \\
\hline \multirow{3}{*}{ Real Estate } & Real estate development and management & 1.20 \\
\hline & Real estate agency services & 1.13 \\
\hline & Property management & 0.66 \\
\hline \multirow{3}{*}{$\begin{array}{l}\text { Scientific Research and } \\
\text { Technical Services }\end{array}$} & $R \& D$ & 1.69 \\
\hline & Professional technical services & 1.42 \\
\hline & Technology dissemination and application services & 1.29 \\
\hline
\end{tabular}

Figure 12 also shows that the lowest premiums in 2007, 2012, and 2017 were for agriculture-a sector that employs a large number of older workers (Figure 14). The combination of a low-skilled and aging population in rural areas could mean a wider income gap between agriculture and the rest of the economy.

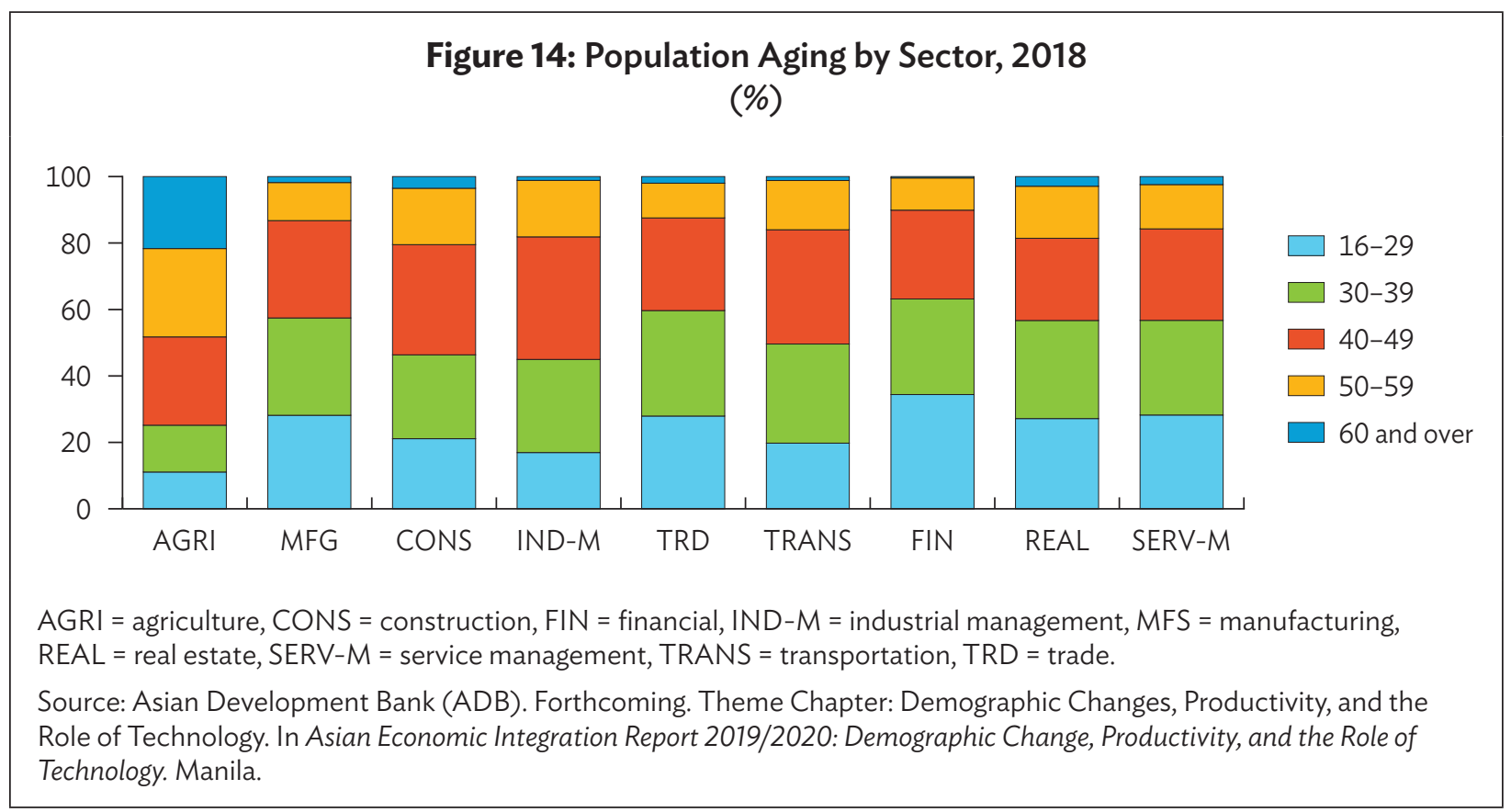


The workforce in sectors with large skill premiums generally require a tertiary education. About $40 \%$ of the workforce employed in these sectors have at least a bachelor's degree from a college or university (National Bureau of Statistics of China 2017). Over $70 \%$ of the workforce in the low-skilled sectors have a middle school education or below.

According to the Organisation for Economic Co-operation and Development (OECD 2015), the PRC's sectoral wage gap is common to many advanced economies. Unequal access to quality education and skill-building services, as well as technological changes favoring higher-skilled workers, will likely further drive income inequality. Moreover, the PRC's structural transformation has brought about major shifts in the sectoral distribution of employment and in the demand for different skills.

\section{LOW ECONOMIC MOBILITY: STRUCTURAL SOURCES OF INEQUALITY}

Four decades of rapid economic growth have moved the PRC to upper-middle-income status, but the country is nevertheless one of the world's most unequal. The impact of this severe inequality on the PRC's social cohesion has so far been moderate, largely due to the success in reducing extreme poverty and to policy reforms that have facilitated labor mobility and maintained high employment. But the PRC's pursuit of quality growth focused on high-skilled sectors and low-carbon industries will likely create job losses and social costs. Policy makers need to take action to abate the potential social and political risks associated with a high level of inequality.

In the absence of strong and progressive social policies, a vicious circle could form whereby inequality in income and wealth reinforces inequality in educational opportunities. If this happens, inequality in job opportunities will get worse, and ultimately stunt economic mobility. This section focuses on various causes of income inequality, among them wealth inequality and the lack of intergenerational mobility in education outcomes.

The decomposition analytical framework developed by Zhuang and Li (2016) identifies four major drivers of income inequality: rising returns to education and the associated skill premiums, income distribution between capital and labor, spatial disparities, and wealth inequality. Regarding the first driver, Jain-Chandra et al. (2018) found that the increase in income inequality in the PRC from the early 1980s to 2008 had been driven by, among other things, differences in education and skill premiums, as well as structural factors (e.g., urbanization and population aging) that were not offset by equalizing policies. The decline in inequality since 2008 is attributable to a decline in the skill premiums for increases in higher educational attainment, declines in geographical and intersectoral income gaps, and an increase in the minimum wage ( $\mathrm{Li}$ and Lin 2015). For instance, the average monthly minimum wage in coastal provinces increased by 95\% during 2010-2017.

The second driver of income inequality stems from the declining share of labor, and the increasing share of capital, in the national income, which is generally unequally distributed. While this trend is seen in many developed and developing countries, it is particularly marked in the PRC, where labor's share of manufacturing income fell from $48 \%$ in the mid-1990s to $42 \%$ in the mid-2000s (Bai and Qian 2009). 
Spatial disparities are the third driver. These include rural-urban and interprovincial spatial disparities, and they account for about half of the PRC's income inequality. These disparities are declining, however. Although spatial inequality (including within the rural population) is declining, inequality within the urban population has increased sharply. The share of urban inequality in total income inequality increased from 25\% in 2005 to $45 \%$ in 2013 (Jain-Chandra et al. 2018).

The fourth driver of income inequality, wealth inequality, is also increasing sharply. The wealth Gini coefficient increased from 34 in 1988 to 79 in 2018 (World Economic Forum 2018), with the share of the national income going to the top 1\% of earners doubling between 1995 and 2015, from 15\% to 30\% (Alvaredo et al. 2018). The major causes are the privatization of the housing sector and the liberalization of capital markets, both of which have reshaped the ratio of wealth to national income. Private wealth relative to national income rose from close to zero in 1978 to over $450 \%$ in 2014, a level comparable with those in France, the United Kingdom, and the United States, due to the sharp increases in asset prices in the housing and capital markets (Piketty, Yang, and Zucman 2017). ${ }^{9}$

Rising urban income inequality, coupled with rising wealth inequality, is particularly alarming in the context of the PRC's rapid urbanization. The large flow of rural-urban migration has pushed the share of the urban population to close to $58 \%$ of the country's total population. One of the main sources of economic insecurity among migrants is the lack of access to affordable housing in the large cities, where housing prices have been rising rapidly. Short- and medium-term policies are needed to deal with housing insecurity in the large cities, as part of the PRC's inclusive urbanization agenda.

As the country moves up supply value chains and shifts to a high-skilled service economy, skill premiums are likely to further increase income inequality unless government policies put a strong emphasis on investments in human capital. It will be crucial to ensure equal access to educational opportunities and to increase the number of workers in high-skilled jobs (OECD 2017; Corak 2013; Coady and Dizioli 2018).

Figure 15 shows a cross-country comparison of education equity, as measured by the Gini coefficient of years of schooling and intergenerational upward mobility in education. The latter is based on the share of adults aged 30-40 (the cohort born in the 1980s) from lower-middle-income families (i.e., with both parents in the bottom $50 \%$ of educational attainment) who had reached the top $20 \%$ of educational attainment by $2018 .{ }^{10}$

9 Private housing stock surged from about $60 \%$ of all housing in 1978 to over $95 \%$ in 2015 ; in capital markets, private ownership of domestic equities rose from near zero in 1978 to about 30\% in 2015.

10 Educational attainment, measured as the percentage of a population that has achieved a certain level of formal education, is frequently used as a proxy measure of human capital. The diploma or certification earned is also used to determine the level of an individual's skills (OECD 2017). Years of schooling is another proxy for human capital. 


\section{Figure 15: Education Inequality and Intergenerational Upward Mobility in Education in Selected Countries, 2018}

Education Inequality

$$
\text { Gini coefficient of average years of schooling }
$$

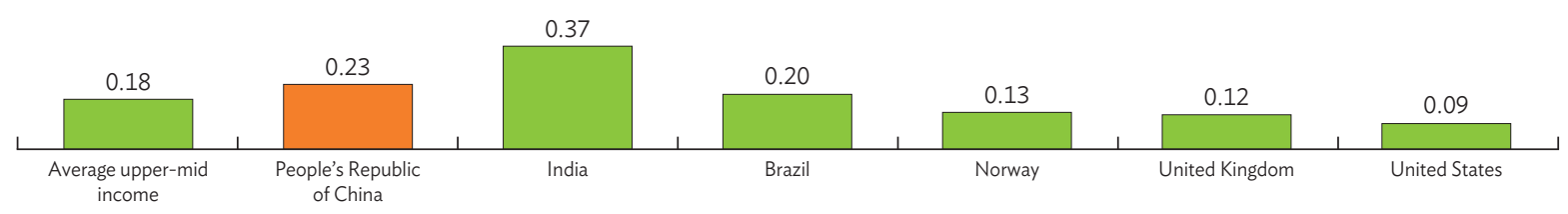

Intergenerational Upward Mobility

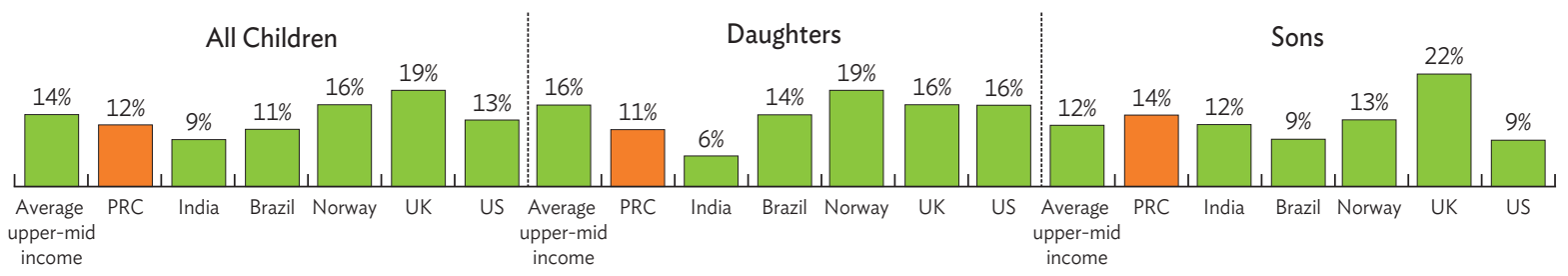

PRC = People's Republic of China, UK = United Kingdom, US = United States.

Notes:

1. The Gin coefficient of average years of schooling applies to the population aged 15 above. The higher the coefficient, the greater the inquality.

2. Intergenerational upward mobility is defined as the percentage of adults from lower-middle-income families who were born in the 1980s and reached the top quintile of educational attainment by 2018.

Source: World Bank. Global Database on Intergenerational Mobility (accessed 9 January 2019).

The PRC performed poorly in education equity outcomes: Its Gini coefficient is the highest among the countries shown in Figure 15, except for India. The PRC's intergenerational upward mobility in education, although slightly higher than in Brazil and India, was substantially lower than the average for uppermiddle-income countries. ${ }^{11}$ A comparison of children born in the 1940s with children born in the 1980s shows that intergenerational upward mobility increased in Brazil, Egypt, India, and Indonesia, but not in the PRC (Narayan et al. 2018).

Gender bias in favor of a son's education is particularly evident in the PRC. Only $11 \%$ of girls from poorly educated families (i.e., the bottom half of the education distribution) reached the top quintile, compared with $19 \%$ in Norway and the average of $16 \%$ in upper-middle-income countries. Boys fared much better in the PRC, with $14 \%$ of those from poorly educated families reaching the top quintile.

11 Despite the lack of official statistics, higher social mobility was widely considered as one of the PRC's major social achievements before the 1990s. For example, a significant proportion of university students came from poor and rural areas in the 1980s and 1990s, as a result of the government-supported rural education system and university scholarships. This trend, however, has been reversing since the 2000 s. 
This is higher than all the countries in Figure 15 except the United Kingdom. The reversal of gender inequality in university enrollment, mentioned above, may reflect the fact that students from better-off families are disproportionally represented in tertiary education, and gender bias is not prevalent among the affluent.

The education gaps are largely found between the rural and urban populations, and between rural-urban migrants and urban residents with household registration; they also reflect the differences in the quality of education between rural and urban areas (Zhang, Li, and Xue 2015). These gaps are significant at all levels of schooling. Figure 16 shows the wide disparities in test scores for math and reading between children in rural and urban areas, and between migrant and local children in cities.

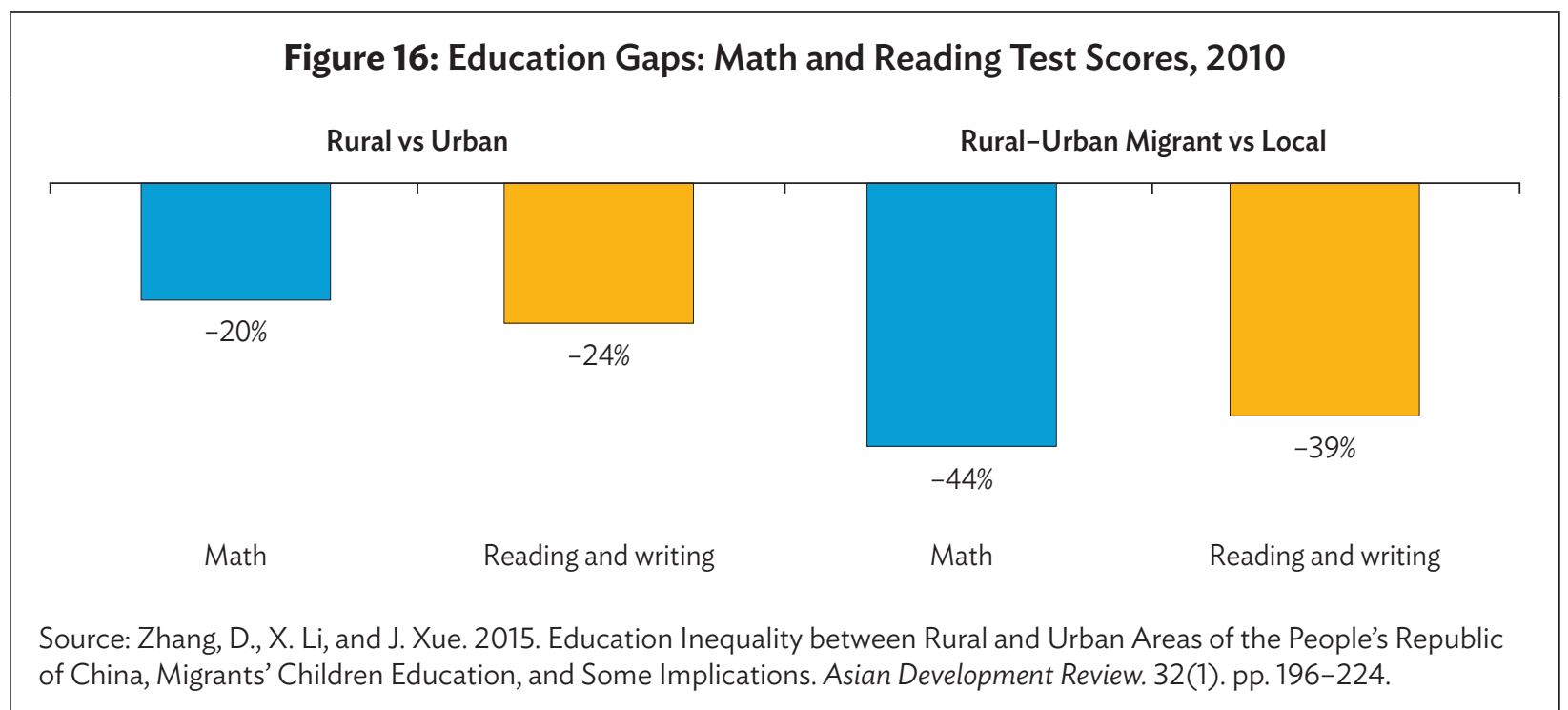

The PRC's highly decentralized fiscal policies require local governments to provide social services. As a result, underdeveloped regions cannot provide high-quality education due to their fiscal and human capital constraints, while major cities can provide high-quality public education. For example, students from Shanghai scored the best in the world for math, reading, and science in the 2012 Programme for International Student Assessment study.

Figure 17 shows that, compared with both developing and developed countries, the PRC stands out for its much lower economic mobility, as measured by intergenerational earnings elasticity. Here, the lower the elasticity, the higher the upward mobility. Low upward mobility in education is probably a major factor in the slow intergenerational earnings mobility. The comparison between the PRC and the United States is particularly striking. While income inequality is at a similar level in the two countries, Chinese children from low-income families have much more limited opportunities to climb the income ladder than their American counterparts. Furthermore, countries that have a tradition of equity-focused public policies and strong government involvement in the provision of social services have a much higher intergenerational mobility and lower income inequality. These countries include Australia, Canada, France, Germany, New Zealand, and the Nordic nations. 


\section{Figure 17: Intergenerational Earnings Elasticity and Inequality in Selected Countries}

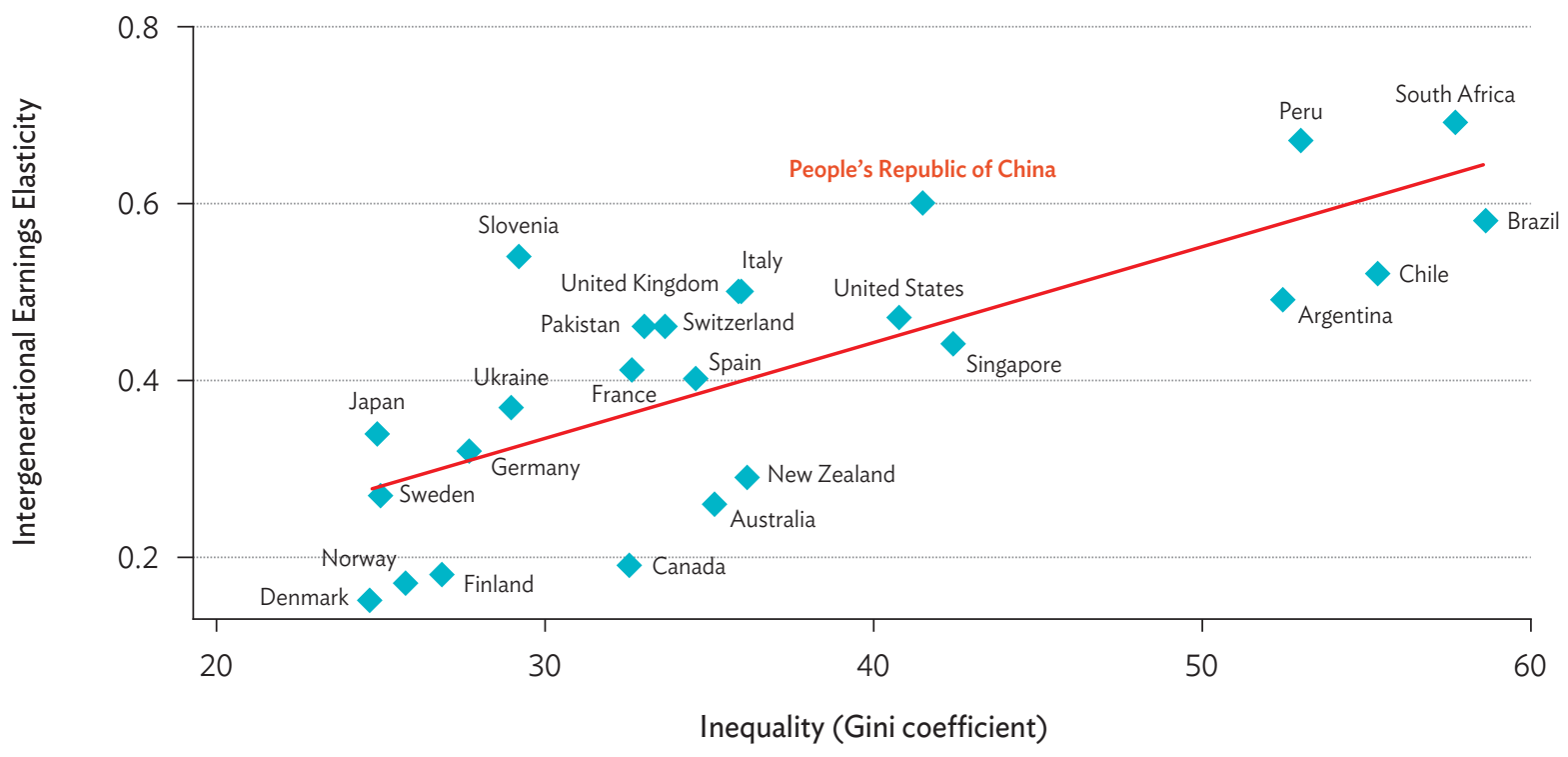

Note: For the measure of intergenerational earnings elasticity, a lower number means more mobility.

Source: Corak, M. 2013. Income Inequality, Equality of Opportunity, and Intergenerational Mobility. Journal of Economic Perspectives. 27(3). pp. 79-102.

\section{MIGRANTS AND INEQUALITY}

The PRC's strategy is to focus on high-quality economic growth and on the New Urbanization Plan (2014-2020), which is meant to accelerate urbanization by integrating migrant populations, and is already causing a massive shift of the workforce across sectors and locations. ${ }^{12}$ This shift, combined with the technological advancement also underway, has generated both new employment opportunities and economic insecurity, as middle- and high-skilled service jobs rapidly expand and low-skilled manufacturing jobs shrink.

Migration in the PRC - both from city to city and from rural to urban areas-is on a scale unprecedented in recent history. Many first-tier cities have become home to a large share of the migrant population, which now averages over a fifth of the population of these cities. According to the World Bank and the Development Research Center (DRC) of the State Council (2014), the PRC's urban population could rise to $70 \%$ of the total by 2027.

12 The New Urbanization Plan is strategically focused on the macro level, and aims to direct national urban policy. It is at the highest level of national plans, much like the 12th FYP. The plan can be seen as a coordinated, top-level effort to increase the population of PRC's cities while addressing critical quality-of-life issues for urban residents. 
Reforms in the household registration system have facilitated this migration, and they continue to play a critical role in promoting labor mobility and reducing extreme poverty in rural areas. But the New Urbanization Plan's objectives of integrating long-term migrants into the urban social welfare system will require the provision of more public services - and the financial resources to pay for them. This level of integration will have to include equal access to education, basic medical and unemployment insurance, an urban pension, and affordable urban housing. The big challenge in the coming decade will be how to ensure social cohesion and an inclusive urban transition, while meeting rising expectations of improved well-being as the government pursues its path toward people-centered, high-quality economic growth.

Figure 18 shows the large variations in the concentrations of migrant population across four municipalities and 27 provinces. In Shanghai, the migrants outnumbered the local residents in 2017, comprising 53\% of the city's total population. Similarly, the proportion of migrants was about 50\% in Beijing. The 2015 National Bureau of Statistics of China survey reported that $36 \%$ of the total labor force were migrants working in cities. Rafiq, Nielsen, and Smyth (2017) show how migrants have contributed to the country's high rate of economic growth.

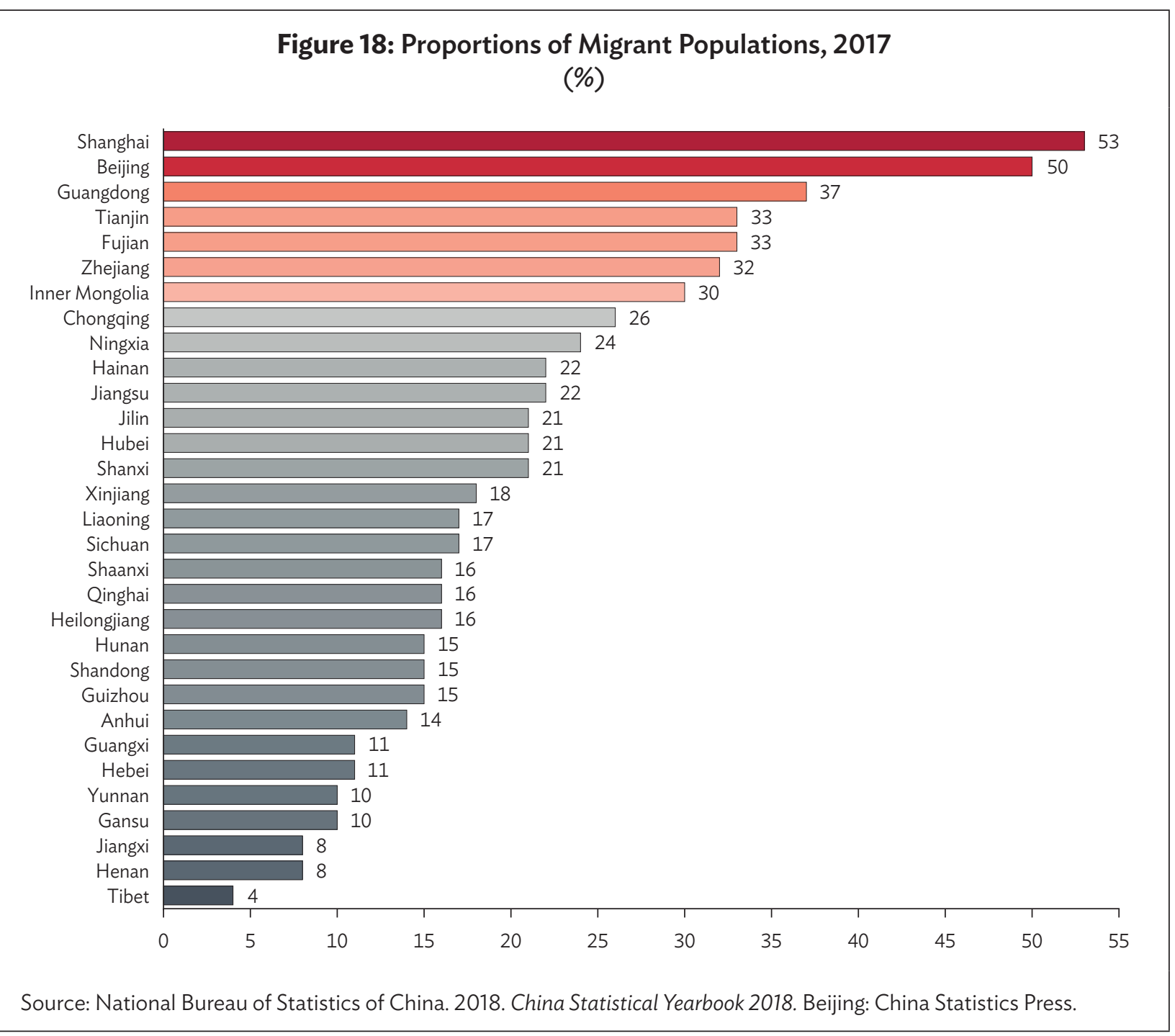




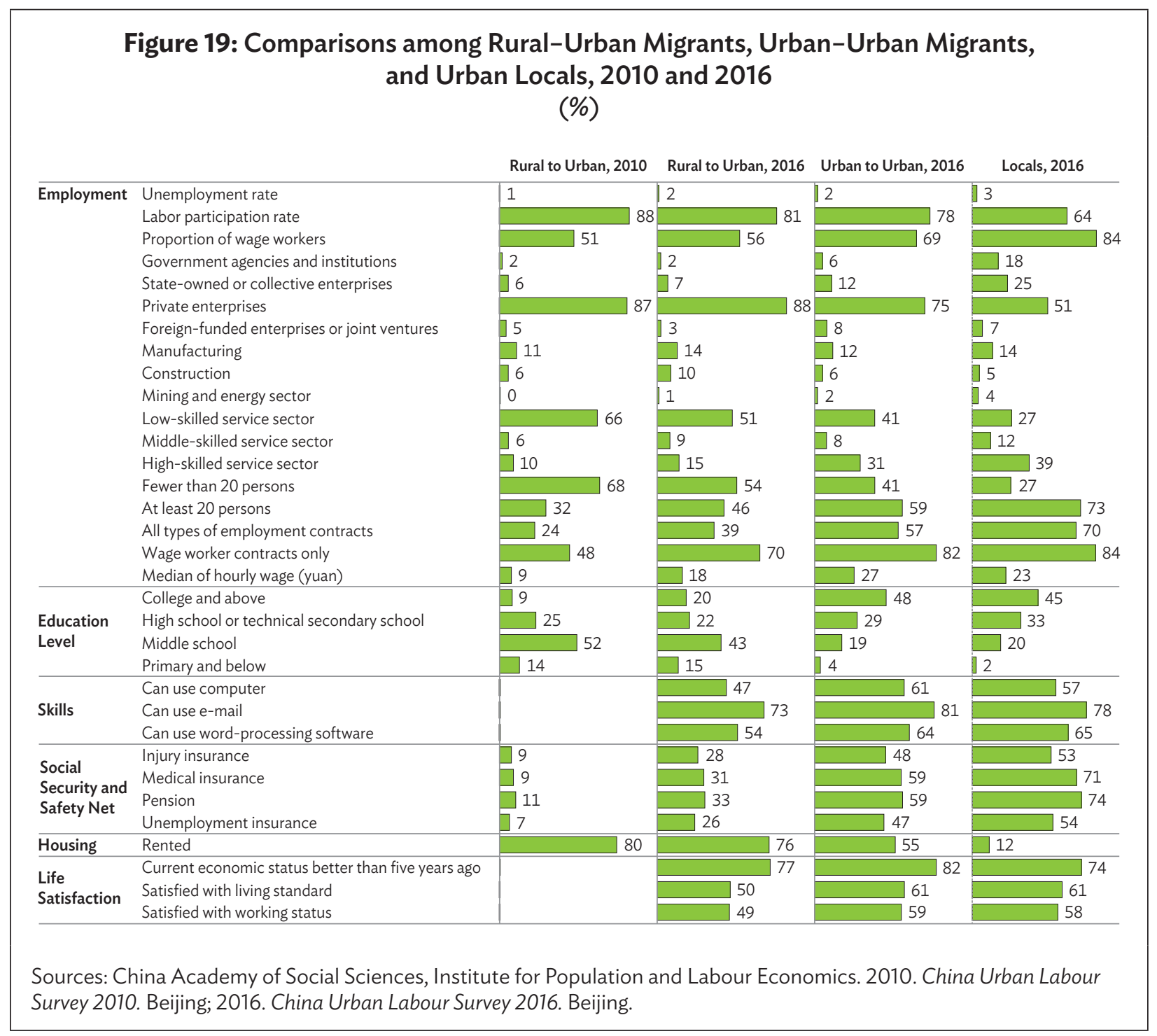

Figure 19 shows how migrant workers have fared in employment, access to social protection, and housing in comparison with urban locals. The figure compares key indicators for these three factors, based on the 2010 and 2016 China Urban Labor Surveys covering six cities (Shanghai, Guangzhou, Fuzhou, Shenyang, Xi'an, and Wuhan). On employment, rural-urban migrant workers were found to be disproportionately concentrated in low-skilled, low-paid jobs and in informal sectors. Among the wage workers, rural-urban migrants were earning the lowest incomes, compared with urban-urban migrants and local workers. Most rural-urban migrants were working in low-skilled jobs in services, manufacturing, and construction, with only about $15 \%$ working in high-skilled service jobs. By contrast, about $40 \%$ of local workers and a third of urban-urban migrants had high-skilled service jobs. The hourly wages of rural-urban migrants were $23 \%$ lower than those of local workers and $36 \%$ lower than those of urban-urban migrants. According to the surveys, rural-urban migrants were largely excluded from jobs in government and state-owned firms, which generally offer more job security, better social insurance, and other benefits. In 2016, fewer than $10 \%$ of rural-urban migrants worked in the public sector, compared with $42 \%$ of the locals. 
Inadequate education explains the poor employment prospects of rural-urban migrant workers. Over half of them have only a middle school education or below, compared with one-fifth of urban workers (Chinese Academy of Social Sciences 2016). The large disparities in education outcomes between the rural and urban populations, and between migrants and urban residents (Figure 16), indicate that targeting social spending to expand access to quality education would be a major pathway toward equality of opportunity and social mobility.

Figure 19 shows how access to social protection and social insurance has evolved. Some progress was made in expanding social insurance coverage to rural-urban migrants between 2010 and 2016. The numbers of those with medical insurance, unemployment insurance, and pensions increased significantly, with nearly a third of migrant workers in the social insurance scheme by 2016, compared with fewer than $10 \%$ in 2010 . But there is still considerable inequality in access to social protection, and the difference in benefits between migrant and urban workers remains large (Wang 2015).

Access to affordable housing is critical for the economic security of migrant workers in the large cities, where rising housing prices have become a major social and political issue. Housing security is one of the most important factors influencing a migrant's decision on whether to bring children and other family members to the cities - and this has implications for the provision of urban public services (education and health care, in particular). Figure 19 shows that, in 2016, 76\% of rural migrant workers lived in rented properties, compared with only $12 \%$ of the local population. Rent accounted for about $17 \%$ of their monthly incomes, which suggests that rising housing prices can have a large adverse impact on housing security for the migrant population. Investing in affordable social housing in large cities should be a policy priority, given the speed and scale of the PRC's urban transition. Reforms in social spending, particularly to equalize social insurance and social protection benefits across cities, and investments in social housing for migrant families, will both be essential for improving the economic security of rural migrant workers.

Efforts to extend social protection and insurance programs to nonwage workers and the self-employed, who make up $45 \%$ of rural-urban migrants, will have to address three issues that are also faced by many developed countries, where about a third of workers are self-employed or on temporary contracts. These are (i) how can means tests take into account fluctuations in earnings; (ii) how can moral hazard be incorporated into unemployment insurance programs for the self-employed; and (iii) what are the limitations for voluntary social protection and insurance schemes, given the fact that high-risk members make risk pooling difficult (OECD 2017).

The experiences of several OECD countries that have tried to develop a universal social protection system offer some useful lessons for the PRC. A combination of different policies-including a universal basic income, the untying of benefits from contributions, and voluntary schemes-has been tried by these countries. Digital technologies could be a game changer for improving the social protection system, particularly for expanding coverage. The PRC's dominant social media platform, WeChat, which had 1 billion user accounts worldwide in 2018 (Yang 2018), has launched electronic WeChat social security cards. This could be an opportunity to improve the management and enforcement of the social insurance system in the PRC.

The next stage of reforms of government expenditure on social security should focus on tackling (i) the wide inequality of access to educational opportunities, particularly between rural and urban areas, but also between migrant and local urban populations; (ii) economic insecurity and the adverse socioeconomic 
impact of the structural upgrading of the economy (e.g., the transition from low-cost manufacturing and energy-intensive sectors to high-skilled services, and the shifting of economic activities across regions); and (iii) the unequal access to social protection and insurance schemes across locations and between migrant workers and local urban workers.

Social spending is low in the PRC, even though its fiscal capacity has increased significantly, in contrast to the many countries burdened by large budget deficits and stagnant growth since the 2008 global financial crisis. The share of tax revenues to GDP, excluding social security contributions, rose from $12.5 \%$ in 2000 to 17.5\% in 2017, backed by strong growth and better tax administration. The cross-country comparison in Figure 20 shows that government spending in the PRC accounted for only 25\% of GDP in 2017 , compared with an average of $42 \%$ in OECD countries. It also shows that government spending in the PRC on health and education was lower than OECD countries. The PRC should further increase its spending on social security and provide additional resources for reaching the disadvantaged. These measures are necessary for dealing with the unequal access to social-protection benefits and insurance schemes between migrant and local urban workers; the unequal access to quality educational services between rural and urban areas and between migrants and locals in the cities; and the lack of affordable housing in large cities for low-income residents, including migrants.

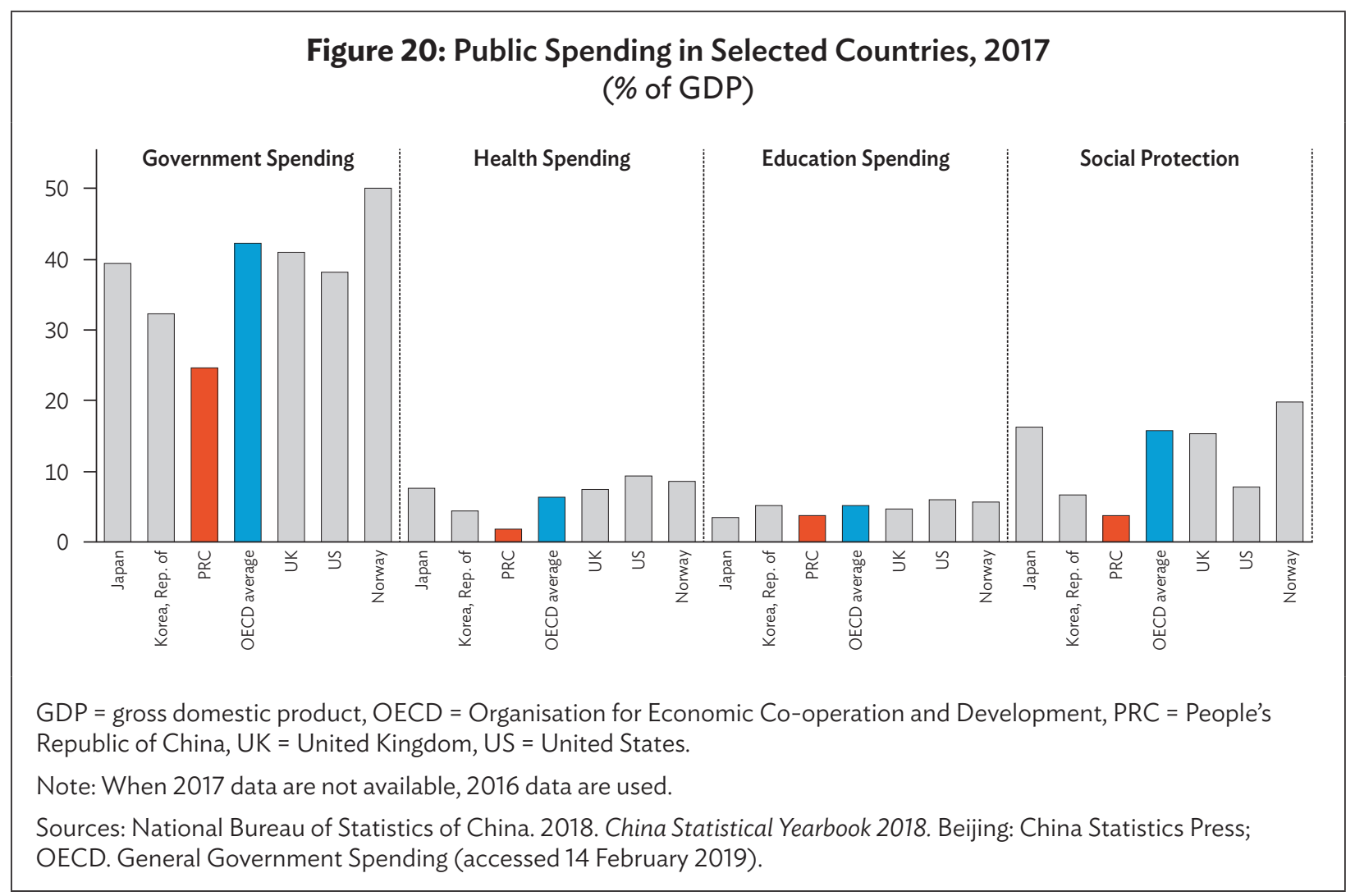


Public finance is at the heart of social services provision. The World Bank and the DRC (2014) estimate that the annual cost of urban public services, social infrastructure, and social housing (factoring in the full integration of the migrant population) will be an annual 6\% of GDP until 2030. Whether public funds can be mobilized to ensure the financial sustainability of these services, and whether the financial disparities across cities can be reduced or eliminated, will determine how successful the PRC will be in accelerating the implementation of the National Urbanization Plan.

Since around 2010, the PRC has carried out fiscal reforms to improve the efficiency, effectiveness, and equity of taxation. These include improving the system of revenue sharing and intergovernmental transfers (Ahmad, Singh, and Fortuna 2004; Ahmad, Neuweg, and Stern forthcoming); reforming tax administration (Brondolo and Zhang 2017); optimizing the tax structure by increasing direct tax revenues and by converting corporate taxes into value-added taxes (Gao 2018; Liu 2018); and transferring social contributions to State Taxation Administration. These reforms have significantly raised tax revenues by expanding the tax base and enhancing administrative efficiency.

Even so, further fiscal reforms will be needed to reduce inequality. Figure 21 shows that the ratios of the personal income tax, corporate income tax, goods and services tax, property tax, and social security contributions to GDP are much lower in the PRC than in advanced countries. This means that there is significant scope for increasing these taxes and contributions without going beyond the government's current taxation-administration capacity. For the same reason, the PRC should consider increasing the tax on capital income.

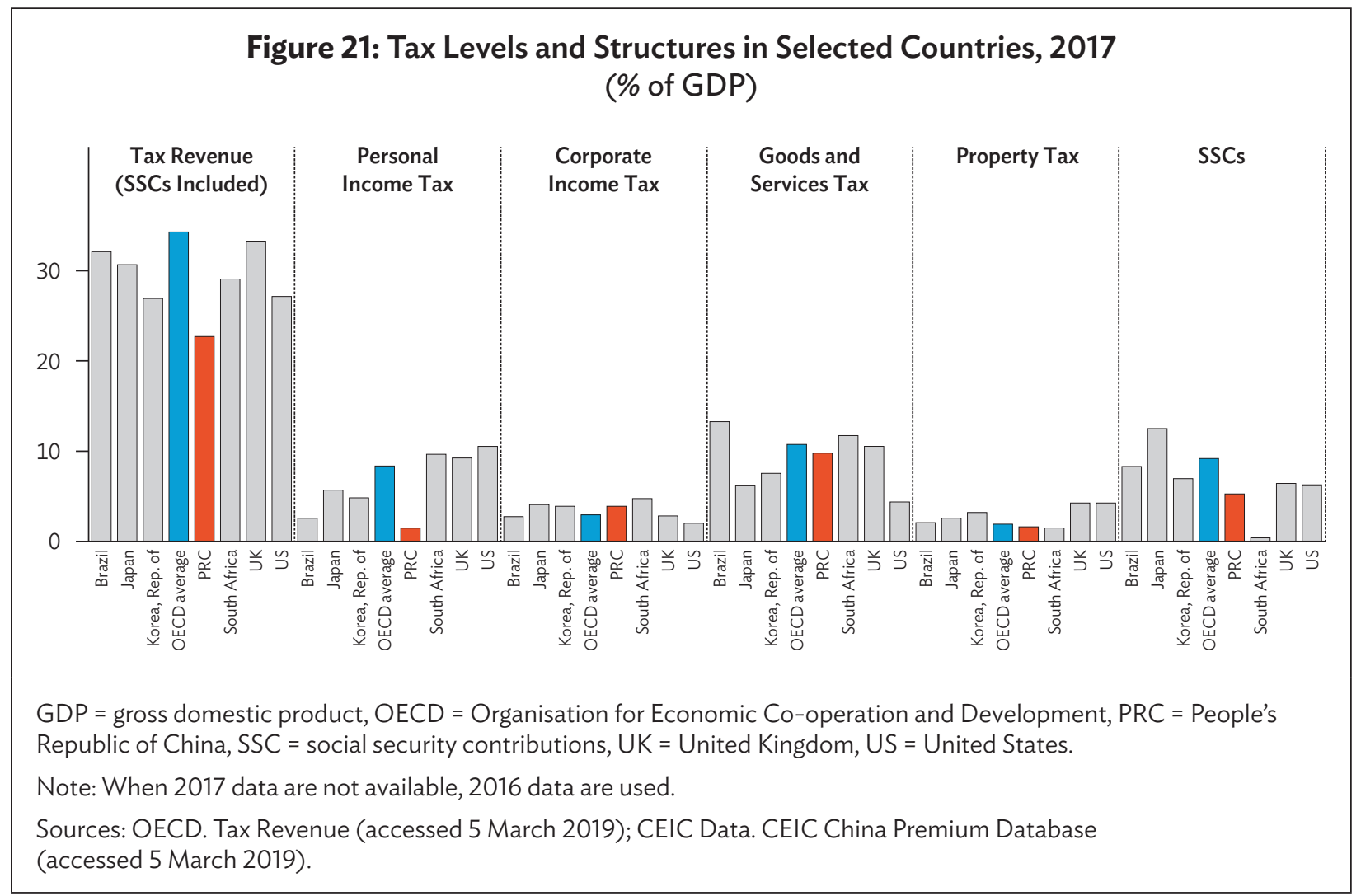


Further fiscal reforms will also have to prioritize the improvement of the tax-revenue structure at the municipal level. Linkages between local financing and the provision of public services in municipalities need to be developed, and should therefore be a focus of future reforms. The current fiscal systemin which local governments have limited revenue-raising autonomy, but are largely responsible for managing public spending and delivering basic services-will become increasingly unsustainable as the migrant population in urban areas increases. This is particularly relevant in the context of the New Urbanization Plan, which aims to develop clean, compact, and connected city clusters; curtail city sprawl and congestion; and reduce reliance on land sales to raise local revenues.

There are several options for mobilizing local public financing that are both efficient and equitable. Two of them are carbon taxes and property taxes. It is estimated that nationally efficient carbon-tax policies would raise funds equivalent to more than $6 \%$ of GDP (Parry, Veung, and Heine 2014). As for property taxes, in large cities with a high concentration of migrants, they could raise an additional 3\% of GDP if the PRC's capacity for tax administration and revenue collection could reach the level of Germany or the United Kingdom (Liu et al. 2017). One should keep in mind, however, that the political and implementation challenges in carrying out the needed reforms could be formidable, as shown in the 2019 political crisis in France over an increase in the fuel tax.

For the PRC, a property tax would be one of the most efficient and progressive fiscal instruments for mobilizing resources to finance local public services, given the fact that the country's high wealth inequality is being driven by private housing assets and rising housing prices (Norregaard 2013). A property tax would, of course, have to be properly designed and implemented. A simple property tax framework developed by Ahmad, Brosio, and Pöschl (2015) and Ahmad (2018), which emphasizes tax-benefit linkages, shows that a property tax would lead to greater accountability and create strong incentives for local government agencies to better manage revenue collection and provide better public services. A simulation analysis shows that a property tax can be a significant source of revenue, which could help cover social service costs (estimated at an annual 6\% of GDP) without increasing the ratio of total government debt to GDP (World Bank and DRC 2014). Research on this topic should focus on a distributional impact analysis of the different property tax proposals and their linkages to the provision of local social services. This research could inform the design of fiscal reforms that would mobilize local resources to finance public services.

\section{POLICY RECOMMENDATIONS}

The key question regarding the maintenance of social cohesion in what Xi Jinping has called the "new era" is how to reduce inequality in educational opportunities, and ensure economic security and income mobility, during the PRC's transition to high-quality development, which involves structural transformation and new challenges.

To achieve people-centered inclusive development, policy makers need to focus on the design and implementation of a range of policies to facilitate the PRC's transition to high-quality development. The immediate policy priorities should include enhancing the resilience and adaptive capacity of the workforce through targeted investments in human capital and strengthened social protection. 
In the medium-term, the priority should be to help workers stuck in low-skilled and easily displaceable jobs to become more adaptive and employable in emerging sectors, such as middle-level skilled services. Interventions should include labor market programs that raise skill levels, to enhance labor mobility and skill matching, and well-targeted and easily administered social protection systems, to tackle the economic insecurity that will be caused by the transition to high-quality development.

Rapid population aging and the advance of automation technologies present both opportunities and challenges. The gradual shifts in the PRC's economic structure and the continued upgrading of its supply value chain has already reshaped the sectoral distribution of employment. This has increased the demand for certain skills and opened up new opportunities for inclusive development.

On the downside, some of the impacts of the new technologies (particularly automation) on the future of work and inequality are now a global concern. These advances are expected to disproportionately affect less-educated workers, especially those with skills that are easily automated. This heightened economic insecurity for certain groups calls for public policies aimed at expanding access to quality education and skill upgrading, combined with social protection programs.

One of the most important challenges facing the PRC during the 2020s is how to manage a coordinated and inclusive transition toward greater urbanization.

In the transition toward inclusive and environmentally sustainable urbanization, cities will be the engine of growth, and will thus be expected to offer new economic opportunities, generate productivity increases, and enable workers and enterprises to share knowledge and ideas with each other. But alongside these opportunities, the new risks of economic insecurity and poverty will arise if social spending and the implementation of public programs lag behind the pace of urbanization, and thus fail to provide all citizens in urban areas with better access to social protection and basic services, regardless of their residency status.

Building on lessons learned from the PRC's economic successes and failures, the government is now working on national strategies to achieve high-quality economic and social development. To this end, the state leadership envisions an open economy in which growth is led primarily by innovation and productivity gains, and where the benefits of development are shared by all. High-quality development means meeting the rising expectations of all citizens for their well-being. Meeting these expectations will be more challenging than simply maintaining stable social cohesion. Against this backdrop, five broad policy recommendations are offered for maintaining social cohesion in the New Era, all of them linked to the PRC's vision and strategies for transitioning to high-quality development.

Poverty reduction. Eradicating absolute poverty will not mean the end of poverty in the PRC. That struggle will continue, but it will change shape as the definition of poverty is adjusted to meet the needs of an upper-middle-income country. This will involve raising the poverty line to a level more appropriate for a country at this income level. Policy makers should consider adopting relative concepts of poverty rather than absolute ones, and they should effect measures to ensure that those who have been lifted out of absolute poverty do not fall back into it again.

Access to education. Among the many factors affecting inequality, access to education deserves particular policy attention. In economies with rising skill premiums, inequality in access to education is an important driver of income inequality and intergenerational income immobility. Increased returns to 
education, reflected in large skill premiums, create strong incentives for private investment in education. Income inequality can therefore reinforce inequality in educational opportunities, and potentially create a vicious circle that stifles intergenerational economic mobility. The PRC's two major education gaps are between its rural and urban populations, and between rural migrants to cities and urban residents. The "left behind" children of poor rural-urban migrants are particularly vulnerable. In their case, the most urgent policy intervention would be to expand the 9 years of compulsory education to 12 years, in order to provide the next generation with at least a high-school education as a foundation for their careers. The quality of education and development of cognitive capacity through a greater focus on early childhood development will be increasingly important for the transition to high-quality development. The potential of online learning to extend educational opportunities, especially for those least served by traditional educational systems, should also be explored.

Lifelong learning. A resilient and adaptable workforce, in addition to having a solid education, should be equipped with skills for lifelong learning, so that people remain employable amid rapid technological change. For policy making, this requires finding the right balance between formal education and skills training. In addition to extending compulsory education to 12 years, targeted skill-upgrading programs, such as technical and vocational training, are needed to provide the workforce with transferable skills. As with compulsory education, these programs should utilize online learning technology.

Access to social services. Social services need to be expanded to cover vulnerable segments of the population, especially rural-urban migrants. They fare poorly in all key indicators of well-being, including employment, access to social protection, and housing security. Rural-urban migrants tend to work in low-skilled service jobs; fewer than $40 \%$ have labor contracts, and only a third have some form of social insurance. Housing insecurity is major poverty risk for them. The fact that $75 \%$ of rural-urban migrants live in rented accommodations reflects the variety of institutional barriers they face in terms of employment opportunities and access to social services. This situation suggests that developing policies to reduce barriers to formal employment and expanding the social protection system will be crucial for improving their economic security.

Improve financing mobilization. The central and local governments need to strengthen the mobilization of financing through (i) capital, property, and carbon taxes, and the enforcement of social security contributions; and (ii) central-local fiscal transfers that are aligned with the levels of concentration of migrant populations. The recommendation for a capital and property tax is justified on the grounds of equity and efficiency. Rapidly rising wealth inequality (driven by nonwage income), the privatization of the housing sector, and the fast-rising housing prices are major sources of economic insecurity for the migrant population, who rely on rental properties. A property tax framework that links revenue with the delivery of basic services will improve accountability and equity. Rural-urban migrants were largely deprived of the windfall benefits from the PRC's housing-privatization boom. But they will likely be major beneficiaries from the expanded access to basic services under the New Urbanization Plan.

The significant gaps in financing and basic services, and the imbalances across cities when factoring in the migrant populations, should be dealt with by broadening the tax base in the cities (e.g., via property taxes) and by modifying the central-local fiscal transfer system, given the large concentrations of migrant populations. 


\section{REFERENCES}

Ahmad, E., 2008. Taxation Reforms and the Sequencing of Intergovernmental Reforms in China:

Preconditions for a Xiaokang Society. In J. Lou and S. Wang, eds. Public Finance in China: Reform and Growth for a Harmonious Society. Washington, DC: World Bank.

_2018. Rebalancing in China: Fiscal Policies for Sustainable Growth. Singapore Economic Review. 63(4). pp. 861-884.

Ahmad, E., G. Brosio, and J. Gerbrandy. 2018. Property Taxation: Economic Features, Revenue Potential and Administrative Issues in a Development Context. Brussels: European Commission, Directorate-General for International Cooperation and Development.

Ahmad, E., G. Brosio, and C. Pöschl. 2015. Local Property Taxation and Benefits in Developing Countries: Overcoming Political Resistance?" In E. Ahmad and G. Brosio, eds. Handbook of Multilevel Finance. Cheltenham, United Kingdom: Edward Elgar.

Ahmad, E., I. Neuweg, and N. Stern. Forthcoming. Policies for Structural Reform in China: Domestic Rebalancing for Strong, Sustainable and Inclusive Growth within and beyond China. In J. Svejnar and J. Lin, eds. China and the World Economy.

Ahmad, E., M. Niu, and K. Xiao, eds. 2018. Fiscal Underpinnings for Sustainable Development in China: Rebalancing in Guangdong. Singapore: Springer.

Ahmad, E., R. Singh, and M. Fortuna. 2004. Toward More Effective Redistribution: Reform Options for Intergovernmental Transfers in China. IMF Working Papers. No. 04/98. Washington, DC: International Monetary Fund (IMF).

Alesina, A., and D. Rodrik. 1994. Distributive Politics and Economic Growth. The Quarterly Journal of Economics. 109(2). pp. 465-490.

Alvaredo, F., L. Chancel, T. Piketty, E. Saez, and G. Zucman. 2018. World Inequality Report 2018. Paris: World Inequality Lab.

Asian Development Bank (ADB). Forthcoming. Theme Chapter: Demographic Changes, Productivity, and the Role of Technology. In Asian Economic Integration Report 2019/2020: Demographic Change, Productivity, and the Role of Technology. Manila.

Bai, C., and Z. Qian. 2009. Factor Income Distribution: The Story behind the Statistics. Beijing: Tsinghua University.

Brondolo, J., and Z. Zhang. 2017. Tax Administration Reform in China: Achievements, Challenges, and Reform Priorities. IMF Working Papers. No. 16/68. Washington, DC: IMF.

CEIC Data. CEIC China Premium Database.

Chinese Academy of Social Sciences, Institute for Population and Labor Economics. 2010. China Urban Labor Survey 2010. Beijing.

_. 2016. China Urban Labor Survey 2016. Beijing. 
Coady, D., and A. Dizioli. 2018. Income Inequality and Education Revisited: Persistence, Endogeneity and Heterogeneity. Applied Economics. 50(25). pp. 2747-2761.

Corak, M. 2013. Income Inequality, Equality of Opportunity, and Intergenerational Mobility. Journal of Economic Perspectives. 27(3). pp. 79-102.

Gao. P. 2018. China's 40 Years of Fiscal and Tax Reform: A Basic Trajectory. China \& World Economy. 26(2). pp. 96-106.

Gass, P., H. Duan, and I. Gerasimchuk. 2016. Stories of Coal Phase-Out: Lessons Learned for China. Winnipeg: International Institute for Sustainable Development.

IMF. 2017. Fiscal Monitor: Tackling Inequality. Washington, DC.

International Federation of Robotics (IFR). 2018. World Robotics Report 2018. Frankfurt am Main, Germany.

Jain-Chandra, S., N. Khor, R. Mano, J. Schauer, P. Wingender, and J. Zhuang. 2018. Inequality in China: Trends, Drivers and Policy Remedies. IMF Working Papers. No. 18/127. Washington, DC: IMF.

Kanbur, R., C. Rhee, and J. Zhuang. 2014. Introduction. In Kanbur, R., C. Rhee, and J. Zhuang, eds., Inequality in Asia and the Pacific: Trends, Drivers and Policy Implications. Abingdon, UK, and New York: Routledge.

Li, S., and C. Lin. 2015. The Impacts of the Minimum Wage Policy in China. CIID Working Paper Series. No. 35. Beijing: China Institute For Income Distribution.

Li, S., H. Sato, and T. Sicular. 2013. Rising Inequality in China: Key Issues and Findings. In S. Li, H. Sato, and T. Sicular, eds. Rising Inequality in China: Challenges to a Harmonious Society. New York: Cambridge University Press.

Liu, Q., A. Gu, F. Teng, R. Song, and Y. Chen. 2017. Peaking China's CO2 Emissions: Trends to 2030 and Mitigation Potential. Energies. 10(2). p. 209.

Liu, Z. 2018. Land-Based Finance and Property Tax in China. ATI Working Paper Series. No. 18-04. Pretoria: African Tax Institute.

Narayan, A., R. Van der Weide, A. Cojocaru, C. Lakner, S. Redaelli, D. G. Mahler, R. G. N. Ramasubbaiah, and S. Thewissen. 2018. Fair Progress? Economic Mobility across Generations around the World. Washington, DC: World Bank.

National Bureau of Statistics of China. 2011. China Statistical Yearbook 2011. Beijing: China Statistics Press.

_. 2014. China Labour Statistical Yearbook 2014. Beijing: China Statistics Press.

_. 2015. China Labour Statistical Yearbook 2015. Beijing: China Statistics Press.

_. 2016. China Labour Statistical Yearbook 2016. Beijing: China Statistics Press.

_ 2017. China Labour Statistical Yearbook 2017. Beijing: China Statistics Press. 
—. 2018a. China Statistical Yearbook 2018. Beijing: China Statistics Press.

_. 2018b. China Labour Statistical Yearbook 2018. Beijing: China Statistics Press.

Norregaard, J. 2013. Taxing Immovable Property: Revenue Potential and Implementation Challenges. IMF Working Papers. No. 13/129. Washington, DC: IMF.

Organisation for Economic Co-operation and Development (OECD). 2015. Skills and Wage Inequality. In OECD Employment Outlook 2015. Paris: OECD Publishing.

— 2017. Future of Work and Skills. Paper presented at the 2nd Meeting of the G20 Employment Working Group. Hamburg. 15-17 February.

_ 2018. The Future of Social Protection: What Works for Non-Standard Workers? Paris: OECD Publishing.

Parry, I., C. Veung, and D. Heine. 2014. How Much Carbon Pricing is in Countries' Own Interests? The Critical Role of Co-Benefits. IMF Working Papers. No. 14/174. Washington, DC: IMF.

Piketty, T., L. Yang, and G. Zucman. 2017. Capital Accumulation, Private Property and Rising Inequality in China, 1978-2015. WID.world Working Paper Series. No. 2017/6. Paris: World Wealth \& Income Database.

Rafiq, S., I. Nielsen, and R. Smyth. 2017. Effect of Internal Migration on the Environment in China. Energy Economics. 64(C). pp. 31-44.

Sirkin H., M. Zinser, and J. Rose. 2015. The Robotics Revolution: The Next Great Leap in Manufacturing. Boston, MA: Boston Consulting Group.

Solt, F. 2016. The Standardized World Income Inequality Database. Social Science Quarterly. 97(5). pp. 1267-1281.

State Taxation Administration of the People's Republic of China. 2013. China Taxation Yearbook 2013. Beijing: China Taxation Publishing House.

Wang, M. 2015. The Design and Implementation of China's Dibao Program. Studies in Labor Economics. 3(3). pp. 79-105.

Wingender, P. 2018. Intergovernmental Fiscal Reform in China. IMF Working Papers. No. 18/88. Washington, DC: IMF.

World Bank and the Development Research Center of the State Council, the People's Republic of China. 2014. Urban China: Toward Efficient, Inclusive, and Sustainable Urbanization. Washington, DC: World Bank.

World Economic Forum. 2018. The Inclusive Development Index 2018. Geneva.

Yang, Y. 2018. China's WeChat Hits 1bn User Accounts Worldwide. Financial Times. 5 March. 
Zhang, D., X. Li, and J. Xue. 2015. Education Inequality between Rural and Urban Areas of the People's Republic of China, Migrants' Children Education, and Some Implications. Asian Development Review. 32(1). pp. 196-224.

Zhuang, J., E. de Dios, and A. Lagman-Martin. 2010. Governance and Institutional Quality and the Links with Growth and Inequality: How Asia Fares. In J. Zhuang, ed. Poverty, Inequality, and Inclusive Growth in Asia: Measurement, Policy Issues, and Country Studies. London: Anthem Press; Manila: ADB.

Zhuang, J., and S. Li. 2016. Understanding Recent Trends in Income Inequality in the People's Republic of China. ADB Economics Working Paper Series. No. 489. Manila: ADB. 


\section{Maintaining Social Cohesion in the People's Republic of China in the New Era}

Since implementing reforms and opening up in 1978, the People's Republic of China (PRC) has experienced strong, sustained economic growth that has enabled the country to reduce poverty on an unprecedented scale. But the PRC's success has brought other challenges-high levels of inequality in income, wealth, and educational opportunities. This paper examines the need to reduce these inequalities (especially between the rural and urban areas) and ensure economic security and mobility as the PRC shifts to high-quality development. It concludes with policy recommendations to promote the achievement of these objectives, which will be necessary for maintaining social cohesion.

\section{About the Asian Development Bank}

ADB is committed to achieving a prosperous, inclusive, resilient, and sustainable Asia and the Pacific, while sustaining its efforts to eradicate extreme poverty. Established in 1966, it is owned by 68 members49 from the region. Its main instruments for helping its developing member countries are policy dialogue, loans, equity investments, guarantees, grants, and technical assistance. 